\title{
A brief examination of warfare by medieval urban militias in Central and Northern Europe
}

Jean Henri Chandler, SDA NOLA, New Orleans, Louisiana

\begin{abstract}
During the medieval and Early Modern period, the Free cities of Central and Northern Europe fielded militias which collectively played an important role in European warfare. The specific military role of the burgher is not well known outside of the realm of academic specialists in the English speaking world. In order to highlight this to my fellow layperson, I have chosen a selection of significant historical events with a special focus on Lombardy, Flanders, Silesia, Bohemia and Poland, in which urban militias played an important role. The intention is to allow us to review the effectiveness, tactics and strategic impact of urban militias and their possible relationship to the martial arts of pre-industrial Europe.
\end{abstract}

\section{Author's notes:}

Special thanks to: Olivier Dupuis, Piermarco Terminiello, Krisztina Nagy, Roger Norling, Christian Trosclair, Willy Rosencrans, Michael Chidester, Cylcia Bolibaugh, Marjorie Dalton and Payson Muller.

For purposes of brevity and ease of verification, the many references to The Annals of Jan Długosz are indicated here in the format Długosz, Date and presented as block quotes.

A note on terminology: It is common in period documents for people writing in one language to use certain imprecise loan words from another. Like using "Tartar" (as in Tartarus) to refer to the Mongols, a term possibly originally derived from Tatar, which is just one of many Central Asian tribes associated with the Mongol hordes. In cases like this, for clarity, I use the term which was most often used in the primary source.

Those of us who have studied historical fencing for a few years have learned the hard way to be wary of trying to force a square peg into a round hole by insisting on direct translations of medieval German or Italian fencing terms into modern English. In this spirit, where I find terms which I cannot reliably translate into English with precision, or worse still where I have to contend with translations without access to the original source, I have made guesses in parenthesis, and left it up to the reader to decide the meaning. All interpretations are provisional!

\section{INTRODUCTION: THE WARLIKE "BOURGEOISIE"}

As a community, though we have come far in our understanding of the fencing manuals, we still know comparatively little about the world they emerged from. As a result we continue to debate many fundamental issues such as whether fencing should be purely for sport, purely for killing, or somewhere in between, and for what kind of 
fighting were the manuals written. I cannot definitively answer these major questions here, but I hope to provide some useful context for further serious exploration of them. For this essay I rely primarily upon a variety of period literary sources, especially the Annales seu cronicae incliti Regni Poloniae ${ }^{i}$ of the remarkable Polish cleric, historian, and diplomat, Jan Długosz, of which I own an abridged English translation. Dlugosz was known to have certain biases, but he remains an insightful period source who personally knew many of the kings and warlords he wrote about.

Where possible I have corroborated his writing with other sources, drawing upon research from a lecture I gave in Boston in 2012 and a work in progress about the medieval Baltic. We have a 13th Century book of combat guild statutes from the militia of Bologna, printed in 1905. The statutes themselves have yet to be translated from Medieval Latin, but the introduction has a description of the basic organization of the militia. A first-hand account by a Flemish chronicler of a street battle between the duke of Burgundy and the citizens of Bruges in the $15^{\text {th }}$ Century, and a period account of a very complex street fight in Prague in 1470 show us how citizens sometimes had to balance on the knifes edge of disaster in order to protect their rights. And a letter from the Hungarian King Matthias Corvinus provides insight into how artisans in his army were paid, and we can see that they were paid very well indeed.

What I hope to do here is first provide some direct evidence of what kind of fighting burghers and craft artisans had to face, for readers to interpret as they like. Second, to show that burghers were fairly warlike, and often had recourse to arms in their lives, both in pitched battles outside of the town walls and more limited but equally important confrontations within them. Third, to show that they could be effective on the battlefield. Fourth and finally, to demonstrate that the battlefield success of the urban craft artisan was linked to their highly developed culture of skilled artisanship in two ways: the technology that they were able to design and fabricate, from town walls and fortifications to new types of weapons; and the techniques that they developed to make the most effective use of the tools at their disposal.

Evidence of burghers association with the fencing and grappling systems of central Europe is fairly well established already, but I will quickly mention two points. In 2007 Olivier Dupuis of Strasbourg made public a detailed analysis of the records of that town, in which he examined the applications for fechtschule tournaments. He noted that majority of the applicants were members of the craft-artisan class, while only $3.5 \%$ were trabant (bodyguards), probably associated with the nobility in some way, while $54 \%$ were textile or leather workersi. We can also note that as far back as the $15^{\text {th }}$ century, many of the fencing masters whose 'day jobs' are known to us were associated with the crafts (see Fig 1). For this reason it is worth looking into the military history of the burgher. Fortunately that history is rich, dynamic, and fairly well documented. 


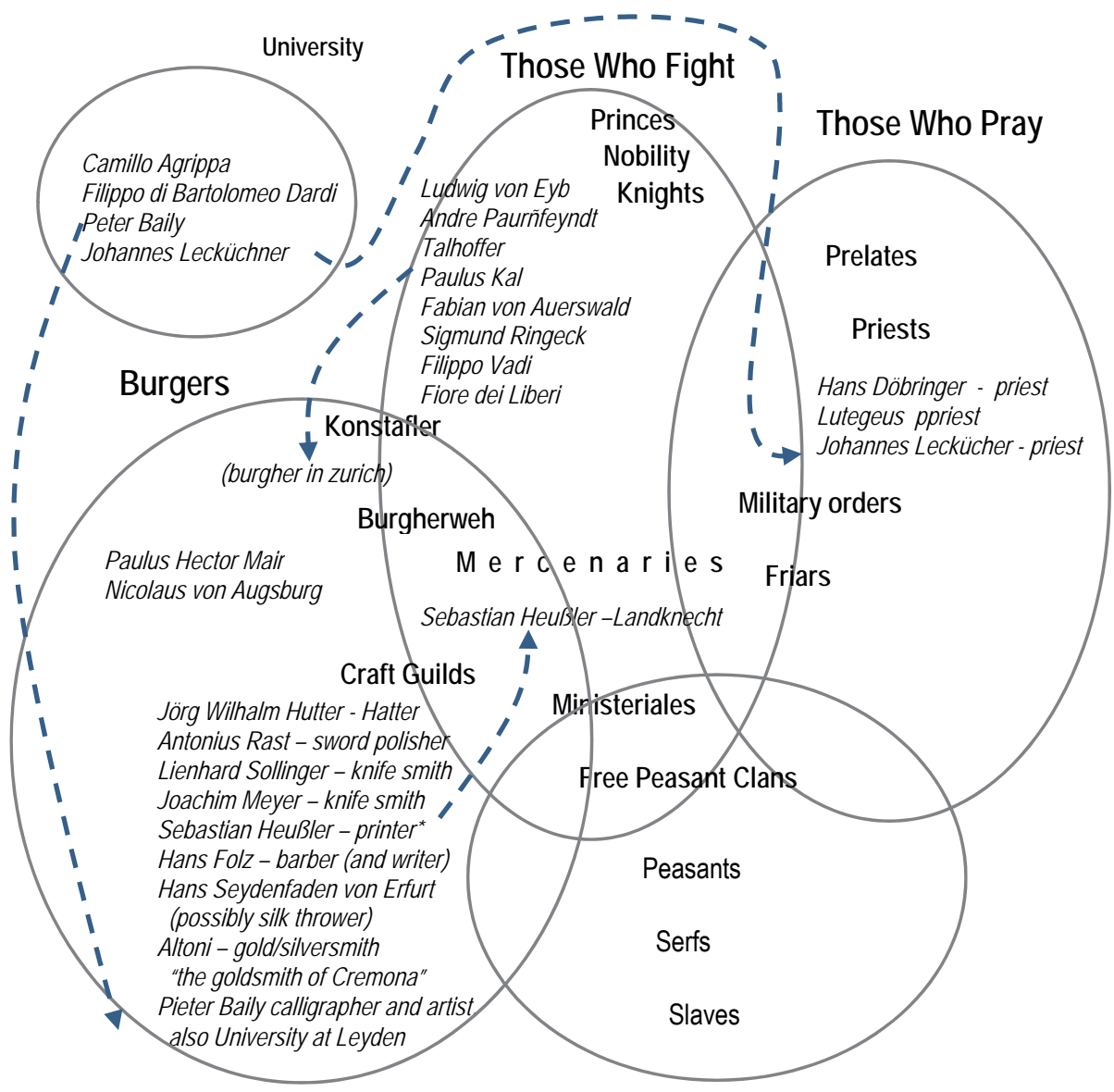

Fig 1 Estates of the Fencing Masters. Image by author with assistance from Michael Chidester.

The most powerful or lucky towns of central Europe went through gradual, fraught transition from the status of mediatstadt (territorial town) to the status of immediatstadt (imperial or royal free city outside of the feudal system) and in some cases into a fullfledged republic. In the Middle Ages the most aggressive towns gradually established large rural territories and some of them reached the legal status of princes. The towns could even become oppressive feudal landlords themselves (for example, in Transylvania or Estonia). In other cases they formed alliances with the rural peasants for mutual protection and trade (such as in Switzerland, Lower Saxony or Bohemia).

Once established, the military power of urban militias remained formidable for generations to come. This allowed for the creation and sustained existence of the urban middle classes in Central and Northern Europe, which in turn may have played an important role in the development of the martial arts we know today as the Kunst Des Fechten, as well as many other innovations in the worlds of art, architecture, astronomy and so on. 
Conventional wisdom is that the military power of the towns peaked and was broken at the Battle of Doffingen in 1388 when a league of several south German cities were defeated by a coalition of princes and the emperor, but this is overly simplistic. Though the offensive capability of some towns declined during extended periods of prosperity,

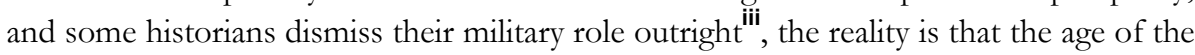
warlike free city would not be over for centuries. First and most importantly, even in the most peaceful parts of Europe, behind their mighty town walls the militia remained formidable in defense, and that was their primary purpose.

Autonomous towns took their defense seriously, which we know by the enormous amount of money and effort they spent on it. For example in 1379 military spending accounted for 82 percent of Cologne's civic spending, and in 1437 between 76 and 80 percent of the expenses of Rostock ${ }^{\text {iv }}$, mostly on upgrading their walls. They had internal industries to produce not only armor and individual weapons for their militias, but also gunpowder and cannon ${ }^{\mathrm{v}}$, for the town arsenals which were world class.

The two most important armor exporters in late medieval Europe were the towns of Milan and Augsburg, and the Venice arsenal was the largest industrial complex seen in Europe until the $18^{\text {th }}$ Century ${ }^{\text {vi }}$. The walls of most free cities were modernized into trace italienne artillery forts in the $15^{\text {th }}$ and $16^{\text {th }}$ centuries, providing a potent defensive force-multiplier which persisted well into the Early Modern era, and this extended the life of the urban militia system and the towns themselves for the next few centuries in an increasingly dangerous European landscape.

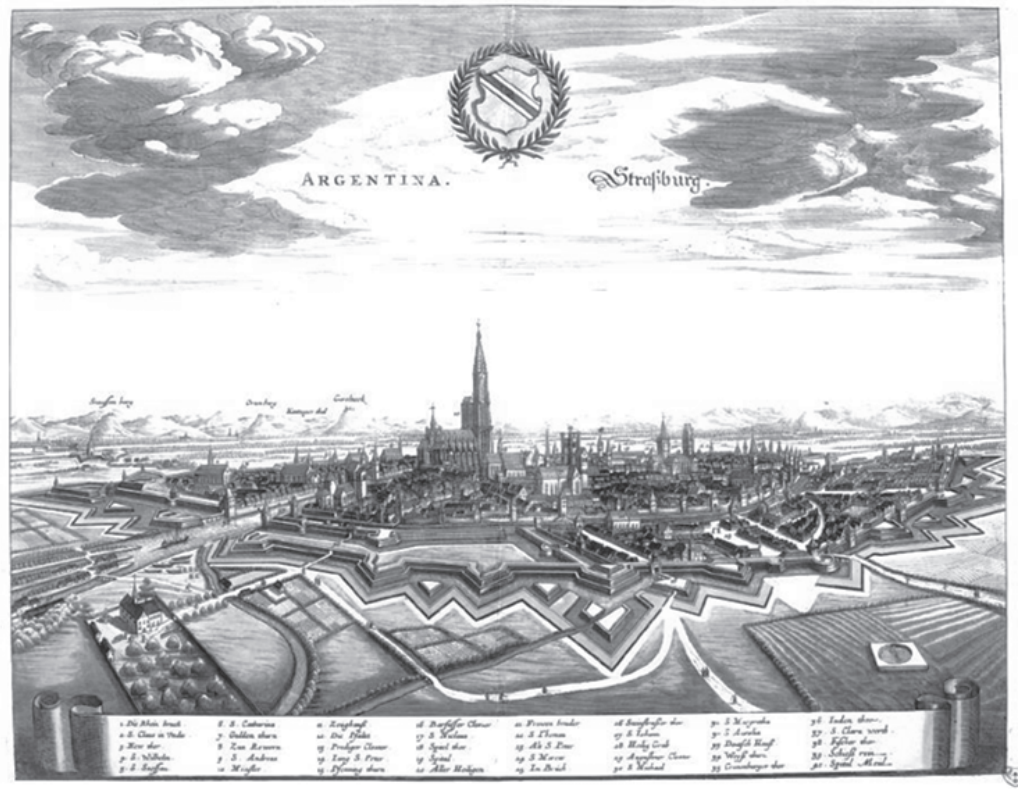

Fig 2. This map of Strasbourg from the 17th Century conveys a sense of what a formidable defensive fortress a free city was 
But it is on the fringes and wild areas of Central Europe, where regional politics were unstable and conflicts with powerful princes and foreign entities were routine, that the military power of the free cities and their militia best demonstrated its merit. In the time of Talhoffer, the most consistent force opposing the expansion of the Ottoman Empire was the urban "serene republic" of Venice. With her 3,000-ship navy and powerful army of mercenaries and militia she controlled the strongest trade network, and also arguably the most effective intelligence service in Europe. Her principal rival, the small but powerful maritime republic of Genoa, still had control of major trade routes to the Silk Road including the trading hub of Caffa in the Crimean peninsula on the Black Sea. Between the two of them they dominated trade in the Mediterranean.

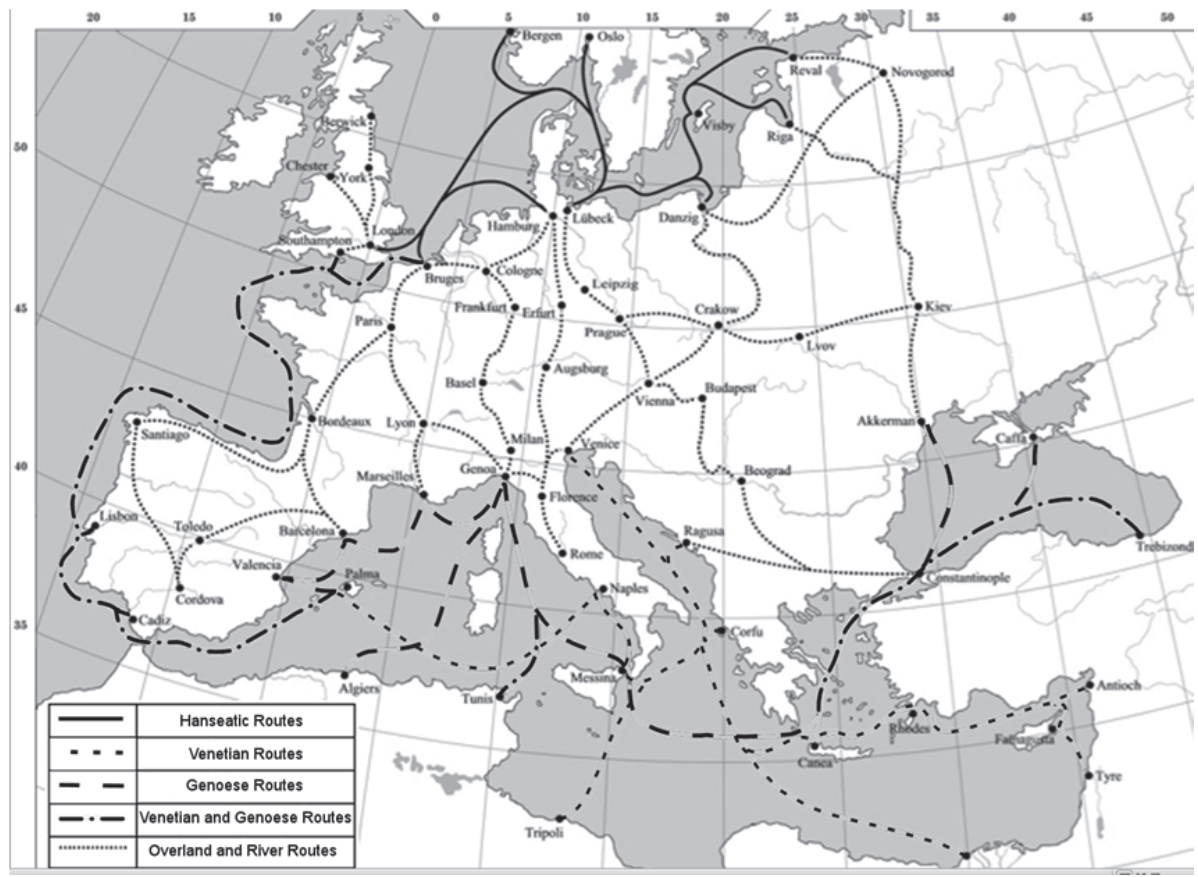

Fig 3. Trade Routes of Medieval Europe

The northern and Baltic sea-trade routes were still largely a monopoly of the Hanseatic League, an urban trade cartel centered on the free cities of Lübeck and Hamburg, which didn't hesitate to defend their interests with fleets of privateers. Flanders, the most dynamic trade zone in Europe after Italy, was the playground of the formidable Flemish cities: Bruges (called the "Venice of the North"), Ghent, Ypres, Liège, and Antwerp, among others, who were linked to the Hanse but also had their own well developed trade networks. The key southern and western German trade routes were dominated by free trading cities such as Cologne, Strasbourg, Augsburg and Nuremberg who linked the Hanse towns to the urban republics of Italy. 
In Prussia the nominally German towns of the Prussian Confederation, led by the free city of Danzig/Gdańsk, fought the successful "13 years war" against the Teutonic Order to join Poland as an autonomous zone from 1454-1466. Later Gdansk would join with Lübeck to defeat England in the Anglo-Hanseatic War of $1472^{\text {vii }}$. Further north and east, the republic of Novgorod, the last Rus city-state to avoid capture by the Tartars, controlled a vast furtrading empire extending deep into Finland and Siberia, and continued to trade with the Hanseatic League until their annexation by Moscow in 1478. In Silesia as we shall see, the town of Wrocław faced off the mighty Bohemian warlord George of Poděbrady, who himself relied on the urban militias of Prague, Tábor, and other Bohemian towns to fend off a major invasion by the Hungarian king Matthias Corvinus.

The militarily powerful Swiss confederation, which would extinguish the mighty Valois dynasty of Burgundy at the Battle of Nancy in 1477, was headed by the small but pugnacious free cities of Zurich and Bern, along with the forest Cantons. And so on. In every case outlined above, urban militias developed major technical innovations and new tactics, often very quickly, in order to cope with nearly overwhelming challenges from the aristocracy, from the Church, and from foreign invaders.

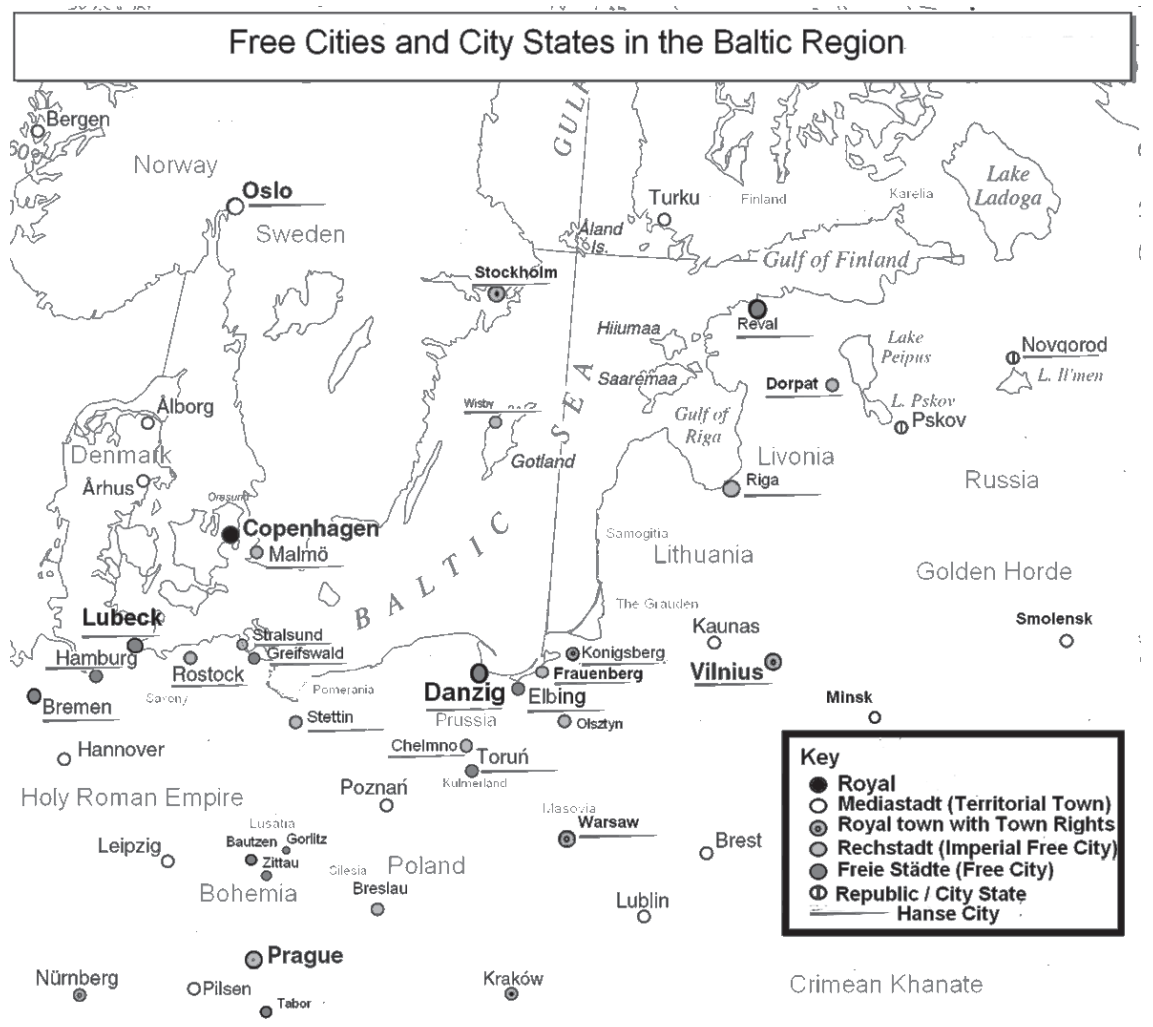

Fig 4. Free cities in the Baltic region. Note that Breslau indicated on this map is the German name for the town known to the Poles as Wrockaw. Map by author. 
The towns lacked many of the strengths of the Kingdoms and Empires had, but they had three important advantages: their walls, their money, and their craft skills, which were fused together into formidable military power through discipline and esprit de corps ${ }^{\text {viii }}$, a delicate and ephemeral quality that most towns took a long time to establish (Verbruggen, 2002) but that some (Wrocław, for example, or Bern) seemed to possess right out the gate. The more often they won battles, it seems, the braver and more successful the urban communes became on the battlefield ${ }^{\text {ix }}$.

Burghers fought as mercenaries, as participants in regional wars, and for their own liberty ${ }^{\mathbf{x}}$ and independence well into the $17^{\text {th }}$ century. Though they relied on mercenaries a great deal, the mercenaries themselves were often burghers and/or members of the extended artisan class, as I will show. Within the town walls, confrontations, riots, uprisings, and stand-offs were so common in the volatile political environment that it was not unusual for the city council to live in fortified homes. But internal violence had to be limited; the important idea of the reze $\beta$ meant that members of the various factions in the towns would often "back down" to keep civic disorder from getting completely out of hand (for very good reasons). The burghers themselves even had to do their duty as urban police.

\section{THE MILITIAS}

Enea Silvio Piccolomini, the humanist and future Pope Pius II, commenting on the state of military preparedness in Germany in 1444, wrote that "not only every noble, but even every burgher in the guilds has an armoury in his house so as to appear equipped at every alarm. The skill of the citizens in the use of weapons is extraordinary." It is worth noting that Piccolomini mentions not just their arms and armor, which we know the burghers had from surviving town records, but also explicitly their skill.

The commune which was the basis of all urban settlements was a pact of mutual protection, and nearly all towns had a militia which was vital to their self-defense. All full citizens (depending on the town, between 5\% and 30\% of the population) and many of their dependents were obligated to fight in the militias and to keep arms and armor in their homes. In fact, in some towns you could be arrested for not owning a sword ${ }^{\mathbf{x}}$. Because only full citizens were members, the militias themselves were fairly small in number compared to the town population, but they could be formidable in the field. They were primarily made up of infantry of one type or another, drawn primarily from the craft guild, which were obliged by Town Law to provide armored men for the burgherwehr, with each group providing a different number, as we see below from the town of Rostock in $1450^{x i i}$ :

De dregher (porters) 150

De shoemakere (shoemakers) 40

De smede (smiths) 40

De beckere (bakers) 30

De haken (retailers) 30 

De kremer (haberdashers) 20
De peltzer (furriers) 20
De knockenhouwere (butchers) 20
De boddekere (coopers) 20
De remensnydere (bridlemakers) 20
De scroder (taylors) 20
De gerwer (tanners) 20
De wullenwever (wool weavers) 20
De vischere (fishermen) 20
De kannegetere (pewterers) 16
De lynnenwever (linen weavers) 16
De repere (hoopers) 10
De murlude (masons) 10
De tymmerlude (carpenters) 10
De oltscrodere (old tailors) 10
De bertscherer (barbers) 6

There are 40 more guilds with a quota of 2 or 3 armed men, for a total of 622 militia. xiii $^{-}$ For the burgher, the militia was the object of pride. Just as a knight considered his military role sacred, so too did the town citizen ${ }^{\text {xiv }}$. They swore an oath of mutual protection and support, often at the site of a sacred tree called a gerichtslinde, in ceremonies which took on a decidedly mystical overtone, and they believed their cause was divinely ordained. Each guild had their patron saint, and this included fighting guilds. St. Barbara was the patron saint of gunners, St. Sebastian of archers, St. George of crossbowmen. St. Michael was the patron saint of the halberdiers guild in Bruges, and St Mark of course was the patron saint of the first known fencing guild in the Holy Roman Empire, the Marxbrüder.

The battle standards of each town and guild were held as sacred objects. In the Italian towns these standards were called the gonfalone, in the German towns the guild banner was called the "fenlin" or "fänlin", literally small gonfalone ${ }^{\mathbf{x v}}$. The Swiss, and the Flemish, too, organized themselves with these town banners, which were also used for military

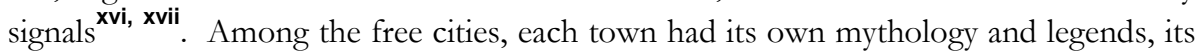
own history of wars won and lost, its own heroes and ideals of patriotism.

\section{CAVALRY}

Most burghers fought as infantry but the towns did also field cavalry, known as konstafler, which was a term denoting both class and a military role, analogous to a knight. Konstafler derives from the same etymological root as constable, comes stabuli, count of the stable. Members of the konstafler societies participated actively in the tournament circuit and many were formally recognized as knights. The patriciandominated towns tended to have more and better cavalry, the guild dominated towns less. For example, the patrician society of the city of Lübeck, called the Lillienvente, 
fielded 402 lances in $1435^{\text {xviii }}$, whereas the equally large but guild-dominated city of Strasbourg in 1363 fielded only 115 lances: eighty-one from the patricians, twenty-one from the guilds, five from the boatmen, four from the storekeepers, and four from the wine merchants ${ }^{\text {xix }}$. In some places the craft guilds formed the bulk of the cavalry; in the city of Wismar in 1483, the militia cavalry was made up of members of the butchers' guild, and members were expected to maintain warhorses ${ }^{\mathbf{x x}}$.

Guild regulations related to the militia tended to be strict, and detailed, as we can see in these excerpts from the craft guild regulations for the shearers of the Flemish town of Arras in $1236:^{\mathbf{x i}}$

7. And whichever brother of this fraternity of shearers does not come to the militia when it is called, shall not remain in the city, unless it is through the aldermen of the city, 20 sous should go to the confraternity.

25. And each master should have his arms when someone summons them. And if he does not have them, he owes 20 sous.

26. Whichever of the brothers does not go around with the burgomeister, the first night that the militia overnights, owes 10 sous.

27. Whichever of the brothers leaves the district by land and by day, and will not embark, owes 10 sous to the confraternity.

28. And whichever of the brothers takes the weapons of the fraternity, if he does not return them on the day that he took them, he owes 20 sous to the fraternity, unless he is keeping them with the consent of the burgomeister and the aldermen.

29. And if any brother begins to mix it up after the militia has been quieted, he owes 40 sous to the confraternity, saving that which is owed to the lord.

30. And at the hour when the mayor and the aldermen order the brothers to arm, he who does not arm owes 10 sous.

\section{OFFENSE AND DEFENSE}

For kings and princes, the urban militias could be valuable allies, since their formidable infantry was often the best available ${ }^{\mathbf{x i i}}$. Knights and men at arms formed a core of professional cavalry, but good infantry was relatively hard to find, and increasingly necessary on the late Medieval battlefield. So the urban militias were sought - after. But they were also somewhat difficult to use strategically as a military asset for a variety of reasons. For one thing they could be unruly. Duke Philip the Good of Burgundy made extensive use of urban militias from Flanders but often faced trouble demobilizing them when they returned home from campaign, especially if they were victorious. They often demanded greater rights and freedoms, which could lead to real trouble as we shall see. 
But the principal limitation to the offensive use of burgher militia was that the towns simply could not afford to suffer large scale losses. Individual burghers did not like going far from their town walls and often imposed severe restrictions upon their commanders regarding their own deployment. For the town itself, it was risky to put so many of their weavers, butchers, bakers - not to mention the hard core of their home defense- into the field where they could be killed, not because they couldn't fight, but because they were skilled labor who took many years to train. Their loss could be crippling to both the town's economy and its defense.

For this reason, in expeditionary campaigns the towns often deployed small, very well equipped units representing a fraction of their militia. These would be augmented by larger groups of mercenaries, thus taking advantage of another important asset of the town: their money. Whereas the nobles had most of their assets tied up in land, the towns had liquid assets in the form of cash and commodities they produced or traded. These could quickly be used to raise an army that they could afford to lose much more than their own citizens. Only when mercenaries could not be trusted and / or the goal was truly critical did the town risk its own militia in offensive campaigns.

\section{WHO THEY FOUGHT. THE RISE OF THE TOWNS IN THE 12 ${ }^{\text {TH }}$ AND 13 ${ }^{\text {TH }}$ CENTURIES}

Though there had been many dramatic events involving towns and their militias, the rise of the Lombard League in the $12^{\text {th }}$ century, during a series of escalating conflicts between towns in Italy and the Holy Roman Emperor is what put the urban armies on the map. The conflict was created when lawyers decided the Emperor owned all the Italian towns by divine right, which the towns themselves rejected. After multiple invasions in which the emperor burned Milan in 1162 and defeated the forces of Pope Alexander III in $1167^{\text {xxiii }}$, the citizens of Milan organized the league which joined together more than twenty northern Italian towns. The greatest military asset of an urban army was its town walls, because siege warfare generally favored the defense, but the towns could not agree which of their number should serve as the battlefield. Needless to say there was a downside for the town being attacked by the imperial army.

So they found an ideal defensive position, and there built a new town from scratch which they named Alessandria after their ally Pope Alexander III. Frederick took the bait and attacked the town in 1162 with a large army of knights and mercenaries, but he was defeated. The mighty emperor invaded Italy a second time eight years later, but was defeated again and nearly died in battle at Legnano in 1176. This crucial victory set the stage for the Italy with which we are familiar in the later medieval period, made up principally of independent urban communes who had little to fear but one another (though that would gradually change...)

The town of Bologna was a member of the Lombard League, and while the details of the Battle of Legnano remain at least somewhat shrouded in legend, thanks to a book of medieval records ${ }^{\text {xxiv }}$ published in the $19^{\text {th }}$ century and now in the public domain, we 
have a very interesting glimpse into exactly what kind of militia was involved in this war. The guild statutes in the book have unfortunately yet to be translated from medieval Latin, but the Italian introduction (hastily translated into English by a friend, Piermarco Terminiello, last year) gives us some insight into the structure of the town's military societies or fighting guilds (societates armorum), which are reminiscent in some respects of the famous fighting guilds of Bruges and Ghent in Flanders.

The introduction states that the book is about the militias that formed the core of the cities' infantry, starting around 1174 when the Lombard League was founded. The actual statutes in the book cover the bylaws and records of twenty-four of these corporations from the middle of the 13th century in Bologna. These twenty-four groups had the names of real and mythological animals, for example the lions, the dolphins, or the griffons. They were for the most part organized geographically, with five societies for each quarter of the city, plus one for men from Lombardy, and another for Tuscans, and a special group, called the stars, for foreigners who did not belong to the other groups. In addition to this the beccai (butchers and possibly related trades like fishmongers and tavern keepers) formed their own separate group.

Their purpose appeared to be to quell civil unrest, to protect against the aggression of the ruling classes, and to carry out external defenses, in which they lined up under their respective standards. Their organization was based on craft guilds, and they were typically governed by four or eight members with an attendant council, who could enact bans and fines on their members. They also had a financial officer/debt collector (for want of a better term), a notary, and a sindacato (something like an internal auditor). Although war was their official purpose, they also served as mutual aid societies for the support of members in times of poverty, burial of the dead, providing for widows of members and so on. They and also had a religious element with members attending masses together in special guild chapels, as was typical of craft guilds.

Important decisions were made by a general assembly, however, that decided on the statutes, expenses over a certain amount, new members, expelling members, and electing officials. It seems that nobles were also initially admitted, but were excluded together with peasants in 1270, and that these militias were involved in the faction wars of 1274 that saw the expulsion of the Lambertazzi family. Though we will learn many new things from the translation of the actual statutes, this introduction gives us a fascinating insight what the organization of the urban militia in the $13^{\text {th }}$ century looks like from the inside.

The organization described in the introduction of this book matches in many respects that of a German market town of the later medieval period. As in Bologna, the German towns organized their militias on the through their guilds, in units by neighborhood ${ }^{\mathbf{x x v}}$. In some towns the militia was organized around the locations of the guild halls, and the elected guild leaders were the captains, in others by the patricians and organized by 
district $^{\text {xxvi }}$ Each quarter had its own captain (called a viertelmeister) and so did each street (a lane captain).

The little sketch we have of the Bolognese militias fits nicely as a counterpoint to some incidents from this same period described by the great Polish historian, cleric, and diplomat, Jan Długosz. Here we can see, from the outside, what the militia of a town from the same era was up against, and how the town was able to use its militia to improve its political position in the region.

\section{Breslau / Wrocław carves out a niche in Silesia. The burghers of Wrocław get their charter, and save a Polish Duke}

During the dynastic struggles under the Piast dynasty, the recently chartered town of Wrocław won town rights and the right to build a wall, by proving to be a very valuable ally for duke Henry of Silesia. They twice defeated his rival, the rather comically villainous duke Boleslav the Bald, whose brutality apparently did not cow the burghers.

Długosz $124 \boldsymbol{8}^{x \mathbf{x i i}}$ : So [duke] Boleslaw bires some Saxon mercenaries and declares war on [duke] Henry of Wroctaw. Henry avoids a pitched battle, for his army is the weaker, thus allowing Boleslaw to plunder the whole territory, in doing which he has 500 men and women, who sought refuge in the church at Sroda, burned alive. He then advances on Wroctaw town and lays siege to it. Wrockaw has been recently located under German law by Henry and is under the government of its Germans. It has few inhabitants and is insufficiently equipped with means of defense, nonetheless it bravely endures a siege of three months, during which, by frequent sorties, it inflicts damaging losses on its enemy, this finally forces Boleslaw to raise the siege with nothing accomplished.

Being "located" means that the town has been surveyed by a professional town founder, called a "locator," and has a town charter of some kind, usually under German town law. Wrocław also located Bochnia in 1253 and Lwow in 1356 under Magdaberg Law $^{\text {xxviii }}$, which linked them to dozens of other cities under the same charter.

The next year Boleslaw the Bald returns to harass Silesia:

Długosz 1249 ${ }^{x \mathbf{x i x}}$ : "When Henry again avoids a fight by confining his activities to defending castles and forts, Boleslaw loots and ravages the towns and villages and sends a great deal of booty of cattle and people back to Legnica. He then again lays siege to Wrockaw town, but without success, and returns home, where his own people seize bim and put bim in prison."

Due to the successes of Wrocław, their rights were expanded by the grateful Henry, and they were allowed to build proper walls. They were also allowed to locate the existing town of Kraków under German town law, thus linking the two towns in a specific legal way, apparently on the theory that it would make Kraków more lucrative to the regional warlords. 


\section{Kraków gets her walls ... just in time.}

The nobility of the district of Kraków and all the bishops and lords of the principal cities of that district, Kraków and Sandomierz, decided to overthrow the duke, Leszek the Black, and replace him with another duke named Conrad of Masovia. Duke Leszek could not trust his own knights, who were switching sides when they saw which way the wind was blowing, so he was forced to rely on the burghers.

Dlugosz $1285^{x x x}$ : "In the end, he has an inspiration: he turns to the citizens of Cracow who are of German origin, entrusts his wife and the castle to them and promises to reward them generously once the enemy has been defeated."

He decided to leave his wife and family in the castle of Kraków, in the hands of the burghers, while he sought reinforcements. This was risky because Kraków the city had no walls, and the entire population had to hole up in the castle during the siege. But the burghers were able to hold out while Leszek traveled to Hungary for reinforcements from the Hungarian king, then returned with an army of Hungarians and Cumans and defeated Conrad. He sent his Hungarian army home with plenty of presents and released most of the rebellious gentry, then he granted the burghers of Kraków the right to build real walls, and conferred autonomy on them. He even adapts the "German" fashion and hairstyle

"The defenders of Cracow, whose loyalty preserved the city for him, are granted a number of privileges: they are allowed to ring the city with ditches, ramparts, bastions and walls, and also, despite the protests of the knights and nobles, he allows the city itself to be administered exclusively by Germans. Leszek now has such sympatby for, and liking of the Germans, that he adopts their manners, dress and way of doing their hair."

The walls were duly built, and like the militia itself, their construction was organized around the craft guilds, for whom the surviving towers are still named. The furriers guild (interesting to historical fencers, due to the association with the Marxbrïder) built and controlled the main gate of the city, St. Florian's Gate, which is still also known as the Furriers' Gate today.

\section{The Tartars Invade}

The haircut may not have had much strategic significance but the people of Kraków were lucky indeed that Leszek the Black granted them the right to build real walls, because just two years later, the Mongol horde made its third invasion of Poland.

Dhugosz 128 $7^{\text {xxi }}$ : They [The Tartars] reach Cracow on Christmas Eve and mount an attack, but lose some of their more eminent warriors and, abandoning the attempt, ravage the surrounding country instead. To do this, they scatter, so that it would have been possible to capture or kill some of them at least, had it not been for the heavy snow and the low morale of the Polish knights. Frightened by the situation, and having no confidence in his knights, Leszek takes his wife and some of his court 
to Hungary and when the Tartars learn this from prisoners, they ravage the country as far as the Pannonian Alps.

There seems to be little if any documentation of this very important battle, which is an afterthought even to Długosz, but it clearly cast a long shadow on the history of Poland. The citizens of Kraków never forgot it; the anniversary of the event is the focus of a Mongol-themed party in Kraków to this day. The following is a quotation from an early $20^{\text {th }}$ century history of Kraków ${ }^{\text {xxii }}$ :

At religious processions, like that on Corpus Christi Day, all craft guilds displayed extraordinary splendour; the members appeared corporately, in holiday clothes, and armed. The seniors, with badges and maces, marched abead, followed by the brethren of the guild, in closed ranks, with ensigns spread and swords drawn.

There was a great parade of the craft guilds on the occasion of the coronation of a king, or a marriage in the royal family, or the triumphant entry of some victorious general. The guilds, marching in arms, gave quite the appearance of a well-equipped body of troops ready for fight- thus reminding the spectators of the important part they had played in the past in defending the city from enemies. For in those times they were the proper defenders of the town walls, providing the bastions with ammunition and implements of war; they all belonged to the rifle company and practiced shooting at the municipal range. The fortified walls of the town had gates, which are mentioned by name in the very oldest book of records: St. Florian's Gate, the Slawkow Gate, St Stephen's, the Shoemakers, the Vistula, and St. Nicholas' or the Butchers Gate; ... Of the towers, the first one, at the outlet of Hospital Street to the east, is perhaps the richest and most graceful. It belonged to the lace-makers guild.

Not long after their victory over the Mongols, the burghers of Krakow faced a new problem when their preferred (and nominal) overlord died, only to be replaced by a relative of a rival duke they had previously insulted.

Długosz 1289 $^{\text {xxiii }}$ This the people of Cracow city do not relish, for they are afraid lest Boleslaw should punish them for having repulsed his brother, Conrad, so they send for Henry IV of Wroclaw, promising to capture both the city and the castle for him. Henry sets out at once with his army. The city fathers, mainly the butchers, at this time the chief guild, order the city's gates to be opened in defiance of Boleslaw's order that they be closed. Boleslaw then slips out of the castle and retreats to the castles of various knights who are opposed to Henry. Although these knights are prepared to fight and beg him not to desert them, [...], Boleslaw decides to go away.

Both the walls themselves and the regional power politics are created or orchestrated by the craft guilds, prominently the furriers and the butchers respectively. By the era of the fencing manuals, the chartered cities were powerful entities which could flex real muscle, financially, politically, and militarily. These towns had their own foreign policy and fought their own wars. 


\section{INTERNAL DISPUTES, GUILD UPRISINGS: CONFRONTATIONS AND COMPROMISE}

Urban strife could be a recipe for disaster for a free city, and often nearly was. Most of the larger trading towns of central and northern Europe suffered periods of violent civil strife over control of the city government as the guilds attempted to increase in power at the expense of the patricians. We know from surviving records of at least 240 risings in forty towns in the Holy Roman Empire alone, though there were undoubtedly many more ${ }^{\text {xxxiv }}$.

The Hanseatic city of Köln (Cologne) experienced 4 full-fledged civil wars between the $13^{\text {th }}$ and $15^{\text {th }}$ centuries: in 1297 the merchants evicted the prince-archbishop in the battle of Worringen and created a new government by the patrician class ${ }^{\mathbf{x x v}}$. In 1370 there was an uprising by the weavers' guild, which was suppressed by the town council. In 1380 two patrician families fought each other in an open war and one was virtually annihilated after entering the town with a small army through a tunnel. In 1392 all the major guilds (spinners, weavers, and dyers, the woollen-drapers, goldsmiths, swordcutlers, and armorers) joined forces to seize power from the "patrician" mercantile class and formed a new government by the guilds ${ }^{\text {xxvi }}$.

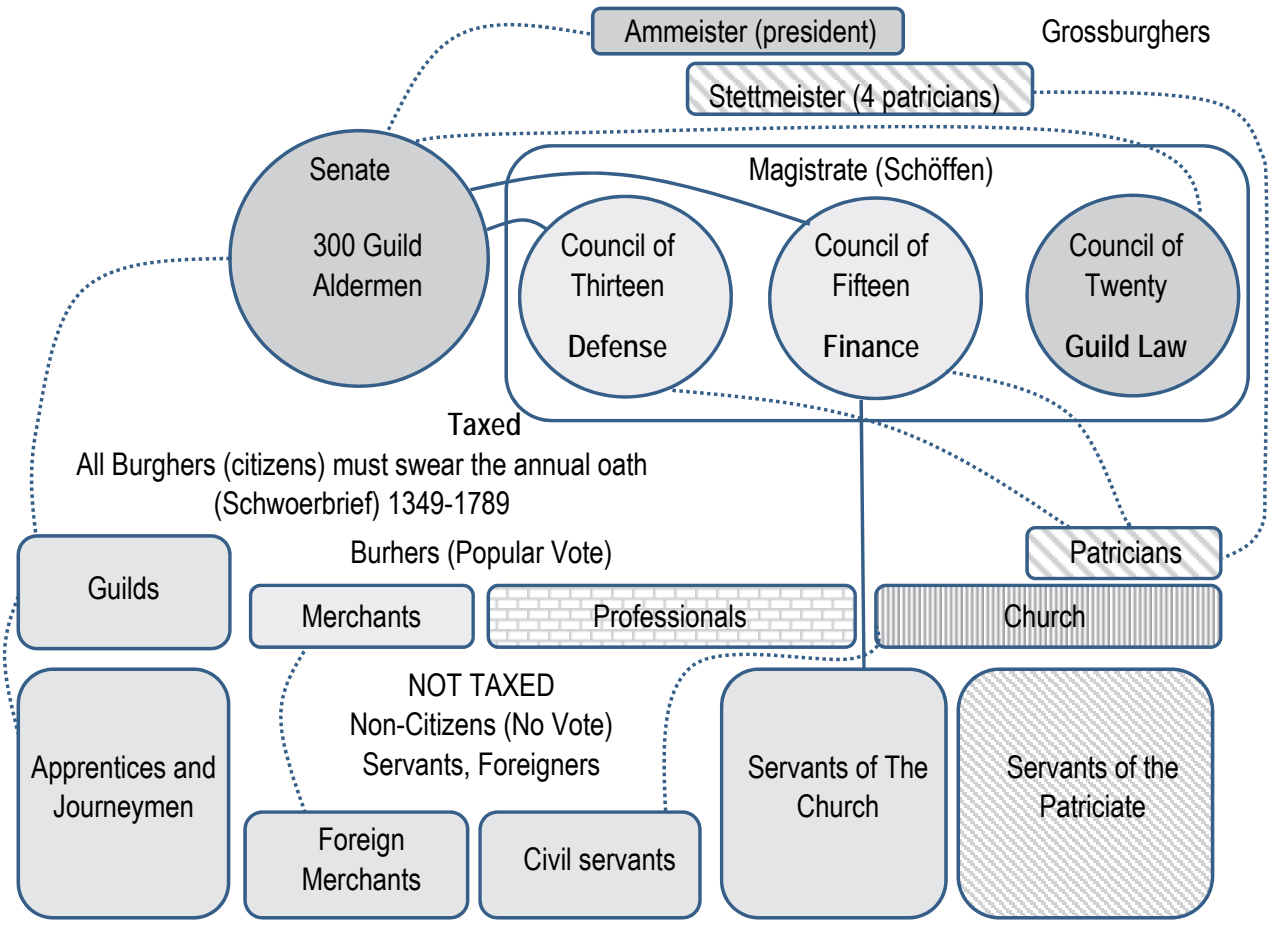

Fig 5, The government of Strasbourg. Chart by author, with assistance from Olivier Dupuis. 


\section{The struggle for control}

In some places the guilds took total control; for example Liège in Flanders won a war against their prince-bishop in 1345 and created a government consisting exclusively of thirty-two guilds which shared power equally, while the patricians were kept out of the town council. On the opposite extreme, the guild-rising of 1349 in Nuremberg was suppressed and the patricians executed twenty-three guild masters and sent another one hundred into exile ${ }^{\mathbf{x x x v i i}}$.

There were good reasons for different factions to fight for power in the cities, as the stakes for control of the town and its markets were very high. But there was also a very strong force underscoring the need to try to preserve harmony. Beyond the walls, powerful warlords were waiting, eager to conquer and pillage the rich cities. Many of these men considered the towns their personal fiefdoms and would seize upon any sign of weakness or disunity to capture them and bring them to heel.

For example in 1371 the northern Hanseatic city of Luneburg was almost captured when the army of Duke Magnus Torquatus managed to slip through the town gates past

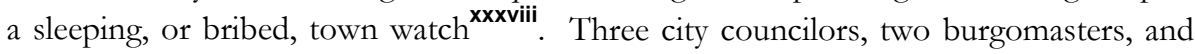
many others were killed in the fighting before the Duke could be forced to retreat after a brutal street battle. In 1366 the large trading town of Bremen was briefly captured by the prince-archbishop Albert II when he managed to take advantage of a dispute between the guilds and the patricians and was let into one of the town gates with the help of some exiled city councilmen. The old town council of Bremen managed to recapture the town shortly afterward in 1368 and soon achieved an internal peace, but it was a harsh lesson. Among other things their sacred statue of Roland, symbol of the city's freedom, was burned. In the long run, Bremen not only recovered but took over virtually the entire estate of the prince-prelate through cunning maneuvers and exploitation of his own vices.

During a dispute within the city of Mainz over the election of a new archbishop for the district in 1461, the city was captured by their former archbishop Adolf II of Nassau ${ }^{\text {xxxix }}$. Adolf was able to enter with a small army when the town watch was caught napping in 1462. He plundered the city and killed 400 inhabitants, and then held a tribunal in which those who had resisted his rule lost all their property, which was divided among his supporters. The rest of the prominent citizens, including Johannes Gutenberg, were exiled or thrown into prison (Gutenberg moved to Strasbourg where he set up the world's second movable type printing press). The new archbishop then revoked the city charter of Mainz and put the city under his direct rule. They lost their autonomy forever on that day.

Because of this risk there was a limit to the severity of the civic power struggle and in the end compromise ruled the day in most cases. Strasbourg fought a series of wars against her bishop in the $13^{\text {th }}$ century, culminating in the Battle of Oberhausbergen in 1262. The city was granted the status of a free imperial city that same year by King 
Philip of Swabia. In 1332 the guilds managed to take power from the patricians and declared the city a "free republic," starting a chain of events which would lead to a total guild victory in 1419 when two thirds of the patricians were expelled from the city ${ }^{\mathbf{x l}}$; but those patricians who remained were gradually recognized by the guild administration as a necessary part of the city, and they granted the patricians some seats on the town council as part of a peace settlement in the later $15^{\text {th }}$ century ${ }^{\text {xli }}$.

In the long run most of the free cities achieved a reasonable level of stability during the $14^{\text {th }}$ or $15^{\text {th }}$ century by reaching a successful political equilibrium, but it was a rough road getting there. We have a classic example of one of these incidents from Wrocław in 1418. Trouble in the city had started as far back as the Wrocław "beer war" of 1380, in which the town got into a conflict with a nearby Polish bishop. The problem was that Schöps beer imported by the Bishop was more popular than the Schweidnitzer beer sold from the cellar (the famous Piwnica Swidnicka) of the city council ${ }^{\mathrm{xlii}}$. For a while the entire city was under interdict (excommunicated) and at one point the bishops Cathedral was ransacked, but in the end a settlement was reached. Tensions continued to simmer however particularly between the patrician dominated town council and the guilds which culminated in the Wrocław guild uprising of $1418^{\text {xliii }}$. Early in the morning of July 18, Butchers and textile workers went to the Church of St. Clements to be absolved in advance of their sins, then barged into the city council chambers where council was in session.

One, named Jakob Krenzberg, a cooper, battered open the door to the tower; Mathes Hengesweib, a brewer, rang the bell. On the main square, in front of the stocks, they executed the mayor; Nikolaus Friberger, Hanns Sachsen, Heinrich Schmeiden, Johann Stille; three advisors, and Nikolaus Faustling and Nikolaus Neumarkt. George Rathburg, a cobbler, chased his own cousin, Johan Megerlin, who had taken refuge in the tower, and threw him ... onto the pikes of the rebellious mass gathered in the Fish Market below ${ }^{\text {xliv }}$

The incident was quite similar to the first defenestration of Prague, and unfortunately for the guilds, two years later the Holy Roman Emperor and King of Hungary was in town preparing to launch a Crusade against Bohemia, and got personally involved in the dispute. 24 guild leaders were executed as a result ${ }^{\text {xlv }}$. Nevertheless, both the city council and the guilds had a disincentive to annoy each other too much, as this could have sad consequences for everybody.

There were also many other types of internal disputes in the towns, we have a good example of a different type of incident in Prague in $1471^{\text {xlvi }}$ :

In August 1471, John Jenec of Janovice, acting as the supreme Prague burgrave, tried to stop the raids of a rebel nobleman, Zedenek. Konopiste. He sought to gather the armed gentry of the region as well as from Prague who, he thought, were duty-bound by virtue of the obedience they owed him to help create public order. 
When they did not obey, he ordered that all the gentry's livestock and horses be brought to his field. The recalcitrant squires hastened to Prague for help, saying that the loss of their animals would cause shortages in that city for several years. When the magistrates ascertained that Janovice intended to march the animals through Prague, and sell the cattle to the butchers, they closed the gates in order to prevent him. [i.e. some of the town council were siding with the gentry]

Janovice hoped not to have to proceed, so he carefully divided the animals into groups for eventual return to their respective owners. He insisted to the protesting city council that he had the right to the animals, and began to move them toward the city's butchers. The squires and their peasants raised the alarm and went after the cattle. When the cattle got to New Town square, the butchers came out with their knives. A general melee broke out, lasting all night, and many were killed. A married woman, Macha Chodouska, participated in the fracas. Seizing a sword from the sheath of one of the bailiffs, she killed several people. In the end, surprisingly, most owners got their cattle back except for the occasional sheep which could not be found.

Konopiste was a robber knight who was interfering with the commerce of Prague, and the burgrave Jenec was obligated to maintain the "peace of the roads", usually by besieging robber knights and destroying their castles. Such incidents were common in the region; in 1438 for example the towns of Zitau and Gorlitz joined forces to evict the robber knights Kryštov Šov of Helfenburg and his companion Švejkar from the famous castle Trosky in the "Bohemian paradise" region (Český ráj)

Jenec wanted to compel the gentry from the area surrounding Prague, who were technically subjects of the city, to help him destroy this robber knight's castle. The book doesn't state who backed down but the claim that "many people were killed" may be taken with a grain of salt. An actual pitched battle would have ended in hundreds of casualties, which would weaken the town significantly since town populations were small. In reality this was probably a sustained confrontation, in which people did fight, but were also exerting a lot of self-control. This was typical of urban political clashes where one side may technically have certain authorities or rights over another faction, but they often had to push them right up to the brink of violence to get what they wanted.

\section{WARS WITH PRINCES}

When a powerful prince got involved in a conflict with or in the town, the stakes were much higher. We are fortunate to have a very interesting first-hand account of just such an event in Flanders. Philip the Good was one of the most powerful princes in Europe at this time, and probably the richest. He was resourceful enough to have held his own in an ongoing hot-and-cold war with France that had lasted his entire life.

The more powerful towns of Flanders such as Bruges were under an uncertain degree of control by the duke and during the preceding three years there had been several risings in Flemish towns pitting the craft guilds against the patricians and the nobility. 
In two particularly severe incidents the burgomeisters of Bruges had been slain by a "riot" of the craft guild militias, and in Ghent Philip himself was captured (but soon released) after his bodyguard was overcome. In 1437 Philip decided to make either a punitive or merely threatening demonstration in Bruges with an army he was bringing on an expedition against Holland, resulting in an incident that cost him dearly. This is one of two competing accounts ${ }^{\text {xlviii }}$, by the Flemish chronicler sympathetic to Bruges.

On Wednesday 22 May [1437] the burgomaster Ludowic van den Walle went to the duke of Burgundy at Lille, and received a letter from the prince for the officers and deans of the craft guilds in Bruges, mentioning that the duke planned to go to Holland with 3000 Picard soldiers who, following the shortest route from Sluis, would go through Male, rather than Bruges. But the duke himself would stay in Bruges for three or four days with his household retinue and up to 500 nobles, in order to see that justice was done for the deaths of the burgomaster Morissis van Varsenare and his brother Jacop. So it was agreed that 3,000 Picards would go to... Male that day and have their meal there, supplies of bread and butter, 4,000 eggs, eight tuns of beer and a vat of wine would be sent out from Bruges. But none of the Picards arrived at Male. Instead, they accompanied the prince to the Boeveriepoort [southwestern gate of Bruges] where, at about three o'clock in the afternoon, all the guilds and societies of Bruges were in procession to meet him... He was held up there for a good two hours by the burgomaster Lodweic van den Walle during which time he sent a knight, the bastard of Dampierre, with eleven companions, into the Boeveriepoort to jam the porticullis so that it could not be lowered before the prince and all his people got into Bruges.

The Brugeois [i.e. citizens of Bruges] noticed with considerable distrust and suspicion that the prince, who was armed, had six or seven battle pennons and some 4,000 people, some wearing battle tunics [i.e. armor], with him... At about 5 p.m. when at least 1,400 men had been allowed in, the prince entered and rode to the Fridaymarket, assuming that those who were still outside the Boeveriepoort would follow bim into town. But the magistrates and the deans managed with great difficulty to close the Boeveriepoort, so that some 2,500 armed men, mostly on horseback, remained outside. They went to the Smedenpoort, but this was shut in time to keep them out. If they had got in, Bruges would have been lost, for the Brugeois were unarmed, since in every gild they had been ordered that morning to turn out in the afternoon to meet the prince unarmed and in their best clothes.

When the prince reached the Fridaymarket with his people, he sent Sir Josse de Heule to the market-place to see if the town authorities had stationed any troops there. When he arrived there, Sir Josse turned to his companions and said: 'We can go straight back to back to my lord of Burgundy. The market-place is his and Bruges is won. We'll kill these rebel Brugeois!'

He rode toward the prince's palace past the mint, and came across the prince with his nobles in the Dweersstraat. As the prince still wasn't certain if the market-place was his, the bastard of St. Pol called out that they should return to the Fridaymarket, and 
though this was full of common people, unarmed, he shouted 'Haubourdin! Haubourdin! Draw our bows! Draw your bows!' [the bastard of St. Pol was Jehan de Luxembourg, lord of Haubourdin]. The archers shot at the people up the street, they shot at the houses, and they shot at the people who were looking, bareheaded, out of windows to welcome the prince. Numbers were wounded, and some 300 arrows remained stuck in the dormers gables and tiles of the houses all along the Dweersstraat as far as the Zuidzandbrugge, on either side of the street. The prince stationed bimself on the higher ground of the Fridaymarket, at the cattle market. There he was with his nobles, armed, holding a drawn sword in his hand, sitting up on his horse while his men either shot at the common people of Bruges or laid about them with their swords, and wounded many. A master baker, Race Ywens, was shot dead as he stood in front of the porcine, doffing his hat in welcome. .. .Thus at the cattle market, the prince's people did battle... and they yelled 'The town is won! Town won! Kill them all!' so loud that their companions outside the Boeveriepoort heard them and some of them tried to swim on horseback across the moat into Bruges...

When the common people of Bruges saw that people were being killed and heard the cry 'Kill them all! Town won!', they rushed back to their houses to arm themselves, and some of the guilds brought small cannons to the Noordzandbrugge and Zuidzandbrugge, and fired wooden missiles at the Frenchmen and the prince's people, who turned and fled back toward the Boevriepoort. But they found it closed. And at St. Julian's a horrible battle was fought. The bastard of St. Pol slew Jan van der Hoghe's son, and two Brugeois were killed by the moat. The other Brugeois saw this and spared no-one. Sonn seventy two Picards had been killed between St. Julian's and the fountain in Boeveriestraat, including the lord of L'Isle Adam, who was struck down dead in front of St. Julian's chapel. The prince, realizing that his people were being killed, rode with a good many of them through the Andgewercstraat toward the moat and the Boeveriepoort. Jacop van Hardoye, the lead night watchman, had in his hosue a hammer, ad pair of pincers and a chisel and, with these, the Boeveriepoort was broken open and, at about 7 pm, the pricne rode out of Bruges toward Lille, with his company. The Burgomeister Lodweic van den Walle, Sir Roland d'Uutkerke, Sir Colard de Commynes the sovereign baliff, and many burgesses... left with him."

It's worth pointing out that Bruges citizens had arms stored in their homes, much as Enea Silvio Piccolomini described in 1444; and the guilds had cannon in their arsenal. Though this incident was extremely violent, both sides arguably practiced some restraint. With a concerted effort, the prince could have burned the city; likewise, if they had been determined to do so, the burghers could have killed the prince. 


\section{A BRIEF NAVAL WAR AGAINST ENGLAND}

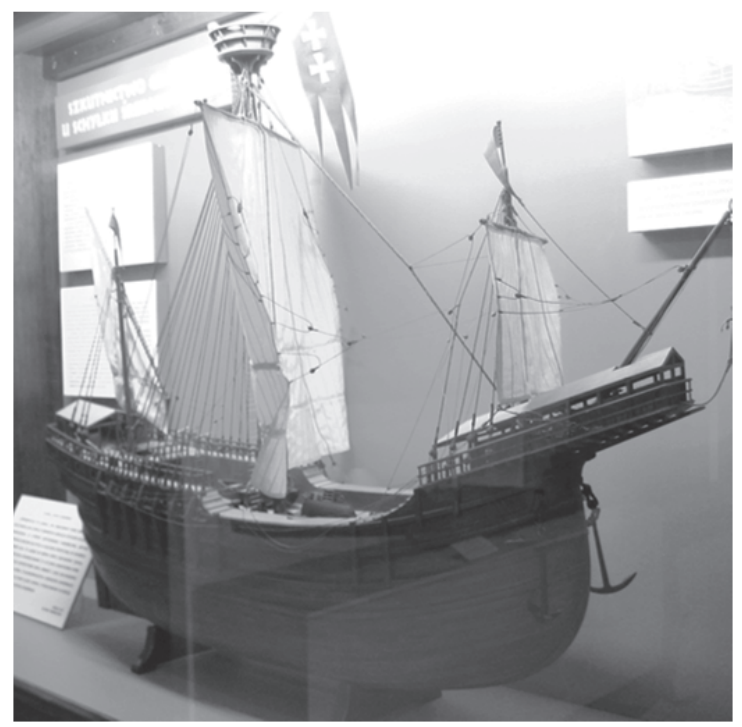

Fig 6, scale model of the Peter Von Danzig. Image by Maciej Szczepancayle

This is Peter Von Danzig. Not the person, the vessel. Originally a merchant caravel abandoned by a French salt merchant in Gdańsk, it was refitted as a privateer by the city at the beginning of the Anglo Hanseatic War in 1466, and commanded by the city councilman Paweł Beneke ${ }^{\text {xlix }}$. The vessel attacked English merchant shipping under a letter of marque and protected Hanse convoys during the war. In 1473, the Peter Von Danzig boarded a Burgundian ship and captured the famous Hans Memling triptych The Last Judgment, (which still resides in Gdańsk today) causing a diplomatic incident with the Duke of Burgundy'. The vessel carried 50 sailors and 300 marines, and mounted 18 guns, probably small caliber weapons. Gdańsk and her principle ally, Lübeck went on to win the Anglo Hanseatic War with the treaty of Utrecht in 1474, resulting in England granting the Hanse the right to a trading base in London called the Steelyard, which they held until $1598^{\text {li }}$.

\section{PUNITIVE EXPEDITIONS AND RAIDS AGAINST "ROBBER KNIGHTS"}

As mentioned previously, it was common for towns to organize expeditions against robber knights or robber barons. Długosz mentions several incidents of this type, of which I have transcribed one involving Krakow.

Długosz, 1452 In the autumn, the dukes of Cieasyn and Oswiecim, having taken offence at being required to pay 2,000 florins towards the cost of the war against Stodek of Brwald, have raided Cracow, despite the fact that one has a treaty of 
perpetual peace with it and the other a truce. The two dukes have hired 9,000 mercenaries, who are busy plundering the province, which is all but empty, as the gentry have all fled the plague, thus the raiders can do almost whatever they please. Although informed of what is happening, King Casimir does nothing. But the Chamberlain of Cracow captures the castle at Malec and another at Bedzin and installs garrisons of a hundred horse and as many foot, with which he forces the two dukes to pay him tribute. The dukes have already collected a considerably booty, including thirteen waggons loaded with merchandise, yet they realize that the kingdom is bound to exact revenge and that what they will have to pay is increasing from day to day, thus, wounded by their own sword, they sue for peace. To obtain this, they have to sign a document to the effect that they started an unjustified war with the kingdom, that they will return all the prisoners they have taken and pay the 2000 florins already due, as well as 800 florins as damages. This done, the fort at Malec is liberated and its people given an exemption from paying tribute."

\section{WAR WITH KINGS AND EMPERORS}

Though most wars between towns and the princes who were their nominal owners were revolutions against the prince-prelate, usually a bishop or an archbishop (in the case of Zurich it was the abbess of a convent), more rarely it was a secular prince, like the Valois dukes of Burgundy, struggling for control over the Flemish towns, or Duke Magnus Torquatus in Luneburg. But it also periodically happened that kings and emperors clashed directly with free cities, and Jan Długosz provides us with several interesting examples of situations like this.

The first excerpt describes a military stand-off between the powerful Silesian town of Wrocław and the nominal king or king-regent of Bohemia, George of Poděbrady, himself one of the most powerful military commanders of his day. The second is a case in which the Holy Roman emperor was held captive by the burghers of Vienna, who were unhappy over some war taxes, leading to his early retirement. The third case describes an incident in which a magnate of Poland was killed after his entourage roughed up an artisan in Kraków. All of these episodes took place in the same region of central Europe and in the fairly short time span of 1459-1463.

Drugosz 1459, Wrockaw vs. the king of Bohemiaii When George Podébrady [King of Bohemia] and his army arrive in Silesia, which is a breach of the agreement, he is welcomed by all the dukes, except the Duke of Zagan. The only town to refuse to admit him is Wroctaw, which dislikes the idea of being ruled by a man tainted with the Wycliffean heresy [i.e. a hussite]. Podébrady plunders and burns many of the towns, manors and villages belonging to Wrockaw, installs garrisons in a number of places and returns to Bohemia. These garrisons have the support of the Crech army and the Silesian dukes, and these make various attempts to capture Wroctaw, which repulses every attack. The Czechs then assault the monastery of St. Vincent, which is near Wroctaw and is a good base for attacking it. The people of 
Wroctaw prepare a number of ambushes and then sally out to attack the Cqechs. As battle is engaged, the people of Wroctaw emerge from their hiding-places, attack the Czechs in the rear and the flanks and have no difficulty in routing them. The Czechs then return to Bohemia.

It's worth making note of the clever tactics used by the burghers to defeat their dangerous enemy.

After this the people of Wrockaw refuse to conclude a truce with their neighbors, the Silesian dukes, on the grounds that they are not to be trusted; but in the end, the persistence of the dukes compels them to do so. Now, two papal legates arrive, sent to persuade the people of Wrockaw that George Podébrady is obedient to the Pope and is intending to unite Bohemia and discard the false doctrine, so they should show him obedience as a king at one with the Catholic Church. The townspeople of Wroctaw, eager for peace, agree on condition that their rebellion is not held against them, that they should not have a governor of whom they may not have approved imposed on them, and that, after a truce of three years, they will give Podébrady their obedience, should be have shown himself a loyal Catholic.

Which he didn't ever do in the eyes of the burghers of Wrocław, so they never made peace with him in the long run. And army of 3,000 Wrocław burghers later captured the town and castle of "Monsterburg" in 1466 as part of a further hostilities against King Podiebrady ${ }^{\text {liv }}$.

Długosz, 1462 Vienna vs. the emperor "When the emperor asks the $V$ iennese for six thousand florins with which to pay for mercenaries to defend the city and the country, four of the city councilors are sent to protest and are put in prison. Vienna revolts and besieges the emperor in the castle, but welcomes Duke Albert, the emperor's brother, when he sails down the Danube with twenty ships, and entrusts him with full authority. Meanwhile, King George of Bohemia has called his people to arms, crosses the Danube by boat at Klosterburg and is secretly advancing to free the emperor; but one of his scouts is captured, so that they are expected and lose 1,000 men; while King George's son loses a further 500 in an attempt to capture Eczinsdorf. After this, peace is made, the conditions being that the Viennese elect the emperor's son, Maximilian, and Duke Albert is made his guardian. The emperor is allowed to return bome.

Here we have a violent incident between a Polish magnate and a craftsman of the city of Kraków which escalated into a major event between the king and the city.

Długosz, 1461 A noble is slain ${ }^{\text {Ivi }}$ While the king is in Wloclawek, there is an unfortunate episode in Cracow, one that is to poison relations between the city and its knights for years to come. On July 16, Andrew of Teczyn angrily rebukes the armourer Clement for failing to deliver a suit of armor on time and for not making it fit; and when the armorer makes a vigorous reply, strikes him, but only lightly. The armourer goes to the town hall and complains that he has been grievously assaulted 
and, on the way back from lodging his complaint, he is accosted by Teczyn, whom be berates for hitting him and, brandishing his fist, threatens to repay the blow with interest; he was, of course, angry and he may have been hoping for compensation; but as a result, Teczyn and his servants fall upon him and beat him. When they learn of this, the City Fathers are indignant and more angry than is justified; .... for they close the city's gates and report the incident to the young Queen.

She demands sureties of 8,000 marks and enjoins both parties to keep the peace and await her judgement, which she will give in the morning, for it is already late in the day, indeed, ten o'clock. The City Fathers return to the town hall and order all householders to arm themselves and assemble there. Meanwhile, the Queen and his friends are advising Tecayn to leave the city and got to the castle. To Tecayn this smacks of cowardice and, with his brothers and friends, be shuts bimself up in a house on Brack a Street intending to resist any attack. Then a bell in the Mariacki Church starts pealing - on whose order no one knows - and this provokes the signal for a riot, which the City Fathers could have quelled with a little common sense and exercise of their authority. Everyone stops work and a crowd, not only angry, but tipsy, presses round the house, intending to kill Teczyn, who seeing that the house cannot withstand such an attack, escapes with three companions and some of his servants to the monastery of St. Frederick and takes refuge in its tower.

Then, convinced that he is not safe even there, though his companions try to restrain him, he leaves the tower and hides in the sacristy. The rioters break down the monastery door and, after a long search, find Teczyn and split his head open. His corpse is dragged through the streets' open sewer to the town hall and kept there for two days, riddled with stab wounds and with the hair singed off its face. Then moved to the Church of St. Wojciech and finally handed over to the victim's friends and relatives. Tecayn's friends in the tower are besieged there all the following day and night, after which they are released. Because of this, the knights of Cracow and Sandomiers at first refuse to take part in the Prussian campaign, but when the king promises that Teczyn's death shall be avenged, they agree to take part."

As a result of the death of this noble, the city was forced to execute eight citizens, and pay the family of Teczyn 6,200 florins. Once the negotiations were over and the penalties had been agreed upon, the city released several hostages it was holding from among the nobles' entourage.

\section{MERCENARY FIGHTING: JAN JISKRA, JAN HUNYADI AND THE BLACK LEGION OF MATTHIAS CORVINUS}

Burghers also fought routinely as mercenaries in the Swiss Confederation as previously mentioned, which was dominated by the towns of Zurich and Berne, as well as other smaller towns such as Lucerne and Geneva. The famous Swiss mercenaries' were often recruited directly in arrangements with the town councils. One could make the argument that their equivalent in eastern central Europe were the hussite heretics of 
Prague and Tabor in Bohemia. The famous Black Legion (Fekete Sereg) of Mathias Corvinus, considered by some to be the first truly modern combined-arms army in Europe since the Roman Empire, was made up largely of Czech hussite mercenaries. Jan Długosz describes an incursion by a henchman of Matthias Corvinus against Poland, using Silesian mercenaries made up of craft artisans, who appear to form a formidable and effective force:

Długosz, 1474 ${ }^{\text {vii }}$ Meanwbile King Matthias [of Hungary], seeking an excuse to provoke the king of Poland, has equipped the Duke of Zagan to fight Wielkopolska. The Duke assembles 4,000 Silesian troops, many of whom are just tanners, tailors, cobblers, and other artisans, and with them some of Wroctaw's guns, made available on Matthias' orders, fords the Oder below Scinawa. Then, since King Casimir as is his habit, is prevaricating and doing notbing, for he considers the matter unimportant, the Duke is able to use the bridge as well as the ford, and so penetrates into Wschowa where he attacks the town. Some of those inside, whom he has suborned, set fire to the town in several places, but the watchful townspeople put out the fires and drive their assailants from the walls. The Silesians then withdraw to an inn, called the Devil's Inn, a mile from Glogow, where they camp and from there they make raids into Poland. The knights of Wielopolska are too afraid to do anything, except one, Peter Gunicki, who with thirty of his followers, attacks a group of the plunderers, and, having routed them, foolhardily attacks the rest of the army round the wagons. Here he finds a glorious and memorable death, though one or two of his men do escape.

Matthias Corvinus, though an ally of the town in their struggle against Poland and Bohemia, openly took a dim view of the autonomy of Wroclow ${ }^{\text {Iiii }}$ :

"You must not take such liberties in future; to fight against Kings, to be disobedient to Kings, to call Kings heretics. It is for the Pope to identify beretics, not for your peasant of V restislav [Wrocław ]."

Despite his distaste for these 'peasants', he had an affair with the daughter of a Wrocław town councilor, Maria Krebs, who he later brought back with him to Hungary, she bore

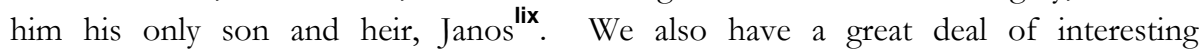
correspondences from Matthias Corvinus himself. In this letter, to a relative in Italy, he describes the makeup and pay of his own army.

(...) the military here divides to three orders: the first of these orders consists of the heavy cavalry; these wish for 15 golds [gulden / guilder] every quarter of a year after every horse, otherwise they won't come here. The other order of the light cavaly, whom we call hussars; these want 10 forints a quarter of a year after every horse, otherwise they won't come here. The third order consists of the infantry, and there are different classes distinguished: as there are light infantry, others are heavy infantry, and again others, the shield-wielders. The light infantry requires 8 golds per person a quarter of a year, the heavy armed and the shield-wielders, since they cannot carry the weapons [crossbows?] and shields [pavises?] without varlets and servants and since they 
must keep these children [sic.] out of necessity, they want to keep these to the weapons and shields with the payment of two people.

Apart from these, there are gunmen, who know their way around guns and pistols [I think this means pistala, which is a Czech word for an early type of handgun. There was no such thing as a pistol in 1481], but neither can they be used for shooting affairs so sedulously, nor as well as the infantry, thus only after the shield-wielders, in the beginning of the clash, (...) and also, they are the best for the siege or protection of castles.

This is a very rough translation ${ }^{\mathbf{x}}$ of a fragment of Mathias' report to his father-in-law, Ferdinand, king of Naples, in 1481. It appears that he is saying the heavy infantry and crossbowmen were paid double, because of all their servants and assistants. That means the pay breaks down as follows:

\begin{tabular}{|c|c|c|}
\hline Type & Quarterly Pay & Annual Pay \\
\hline Heavy cavalry / lancers & 15 florins & 60 florins \\
\hline Light cavalry / hussars & 10 florins & 40 florins \\
\hline Light infantry & 8 florins & 32 florins \\
\hline Heavy infantry & 16 florins & 64 florins \\
\hline Shield Bearers (Crossbowmen?) & 16 florins & 64 florins \\
\hline
\end{tabular}

Which means the more elite among the infantry were actually paid more than an individual lancer. However a full "lance" (the lance was one of the basic units of heavy cavalry in the medieval period) usually consisted of four or five horsemen. Nevertheless, this seems to show that the elite among the infantry, who we know in this case were often artisans and burghers, could be paid more than a lancer, as was appropriate for "skilled labor," both on the battlefield and off. In fact this is the same way guild masters were often paid - they received the equivalent of their own wage for every apprentice or journeyman in their employ.

\section{MERCENARIES GO ROGUE}

The Moravian mercenary Jan Jiskra, a rival of Jan Hunyadi (the father of Matthias Corvinus), also operated in Hungary using Bohemian mercenaries. Jan Długosz, who in addition to being a priest and historian was a highly successful diplomat, knew both men personally because he negotiated a peace treaty between the two of them in 1450 . Jiskra, as a Bohemian representative of the faction of Ladlislaw "the Posthumous" during his minority in the Hungarian interregnum, was in an interesting situation in Hungary.

Like many warlords of his day, Jiskra relied directly upon the towns mainly in northern Hungary (and largely what is now Slovakia) for his supplies, weapons and manpower ${ }^{\text {Ixi }}$. Though his troops proved effective against the Turks, they were problematic to the Hungarian and Austrian nobility due to their habit of spreading heretical ideas and raiding abbeys and monasteries. As hussite heretics they were antagonistic to the 
Catholic Church. The decision was made to liquidate them and drive out Jiskra, who became the victim of some intrigue against him in Hungary, and, after losing most of his property, left temporarily to fight for the Teutonic Order in Prussia.

The Bohemian mercenaries however elected new leaders and formed heretical bandit groups called bratrici, who then proceeded to take over several castles and abbeys in the area and adopted a lifestyle of plunder and robbery for their survival. They proved difficult to eradicate, defeating several efforts to dislodge them. The bratrik bands had been active since the 1440s but were becoming particularly difficult by the 1450s. In addition to being heretics, they showed somewhat communistic or millenarian tendencies, according to a report given to the Pope by Piccolomini in $1453^{\text {Ixii }}$.

In order to regain control over the bratríci, who had apparently reached the number of 20,000 men, Jiskra was given back some of his lands in Northern Hungary and was asked to regain control over his men. Most of his former soldiers went back over to him, but many of the bratríci remained ensconced in fortresses and towns they had taken over, and neither Jiskra nor anyone else could dislodge them from their 36 strongholds ${ }^{\text {Ixiii }}$.

Jiskra made a show of fighting the bandits, outlawing their most feared leader Axamit, who was from near Tabor in Bohemia, but in practice he rarely clashed with them, and gradually, Northern Hungary became the fiefdom of these people, and the queen Erzsébet herself ${ }^{\text {xiv }}$ relied upon them for protection during the dangerous interregnum between the death of Jan Hunyadi and the maturation of his son, Matthias. The power of the bratrici as a political force in Hungary was broken when they were decisively defeated in battle in 1467, but the region of Northern Hungary remained a haven for hussite mercenaries, and this according to some people, was an early step toward the founding of the Slovakian nation.

\section{HOW THEY FOUGHT: THE TECHNOLOGY OF WARFARE}

The burghers of the craft guilds faced professional warriors, knights, mercenaries, and steppe nomads, all of whom could devote a lot more time to training and combat experience than a full-time weaver, cutler or butcher could. To face this they had money, their formidable town walls, and their culture of knowledge and skill. One of the ways that skill manifested itself was in developing better and more sophisticated weapons, and better and more sophisticated tactics with which to use them.

Weapons were serious business in the towns. Most free cities had specialists such as fletchers, cutlers (i.e. swordmakers), stable-hands, crossbow-makers and even cannonfounders ${ }^{\mid \mathbf{x v}}$, as well as master masons, alchemists and architects who all contributed to the town defense. It was also common for towns to hold gun and crossbow marksmanship contests, and most towns had municipal shooting ranges. 


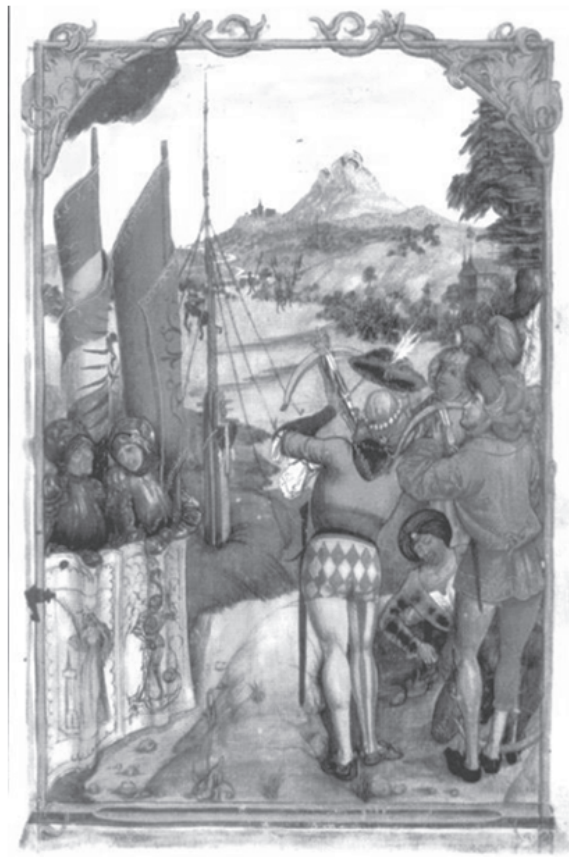

Fig 8 "Shooting the popinjay", from the

Balthasar Behem Codex, 1505 AD.
The popinjay (parrot) was made of wood in different parts, like a puzzle, and each part was marked for a prize. Dlugosz described a scene in which a fire raged out of control in Krakow because all the apprentices were outside of town, shooting the popinjay. Jan Długosz describes how he almost lost his house in a fire in Krakow because all of the apprentices were outside the town walls 'shooting the popinjay' and were not at hand to put the fire out.

\section{The crossbow}

By the time of the First Crusade, the European crossbow was beginning to find a niche as an important new weapon in the world. Experience with the formidable composite bows of the Turks may have inspired the new composite prods (the prod is the bow part of the crossbow) which seem to have appeared by the $11^{\text {th }}$ century, made of horn, wood, sinew, and other organic materials. They were much more powerful than the allwood prods used in earlier eras, but also harder to make and more difficult to use. The crossbow of course rather famously had some inherent disadvantages compared to the bow, but it also had some advantages - a better range for direct shots being one, and the ability to ready a shot indefinitely being another, and probably the best accuracy of any ranged weapon of this era. The traits made it ideal for siege warfare, which was the niche it occupied in most of the world outside Europe. 


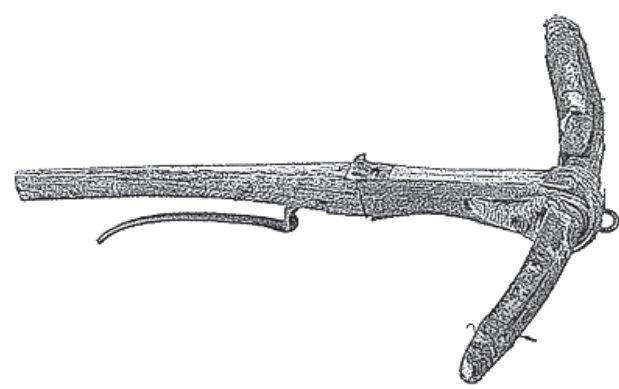

Fig 8. 15 $5^{\text {th }}$ Century crossbow, authors illustration based on antique. The very thick prod is characteristic of composite prod weapons from this period. The composite prods remained in use alongside steel prod weapons through the $15^{\text {th }}$ Century.

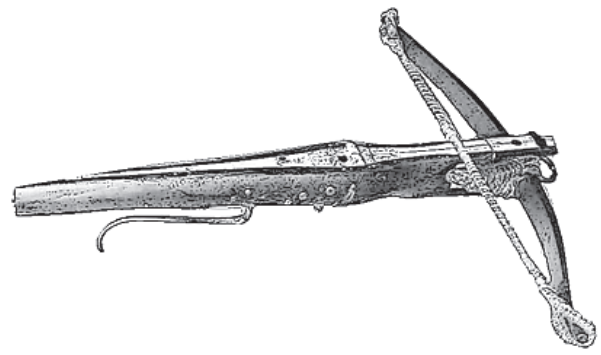

Fig 10. Another 15th Century crossbow, this one with a steel prod. Illustration by author based on antique. This may be a bunting weapon

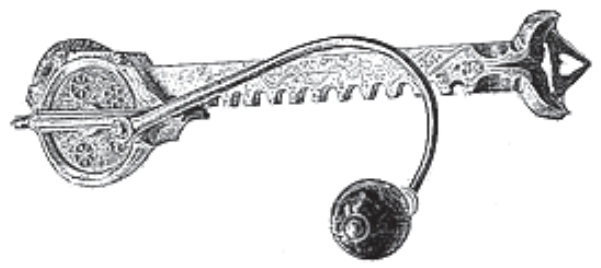

Fig 10. A cranequin spanner, 1512, illustration by author based on period antique.

Note the astrological symbols engraved into the sprocket.
But in central Europe in particular the crossbow was very popular, eclipsing other ranged weapons on the battlefield. Composite prod crossbows began to gradually be replaced by spring-steel prods starting in the $14^{\text {th }}$ century, some of which could reach up to 1,200 pounds of draw strength. Weapons of this power are dangerous and tricky for amateurs to handle, and needless to say, loading or spanning one was more than could be accomplished using muscle power alone.

But the artisans of the medieval cities were resourceful. By the $14^{\text {th }}$ century new spanning devices were appearing on the battlefield (as we see in period art and written records) alongside the new weapons. The lever-operated goat's-foot and the similar wippe allowed very powerful crossbows (up to 500 pounds of draw ${ }^{\text {Ixvi }}$ ) to be fairly easily spanned, allowing the increasingly widespread use of mounted crossbowmen such as we see in Talhoffer.

The more powerful cranequin reductiongear device (similar to the jack one uses to elevate a car in order to change a spare tire) allowed weapons of up to 1,200 pounds draw or more to be used fairly easily by a skilled marksman, including from horseback. Though not as fast to span as the type which used the goat's foot, weapons of this power, often referred to in period records as halb rusting (half ton) and as the stachel (stinger), could apparently kill horses with a single shot. 


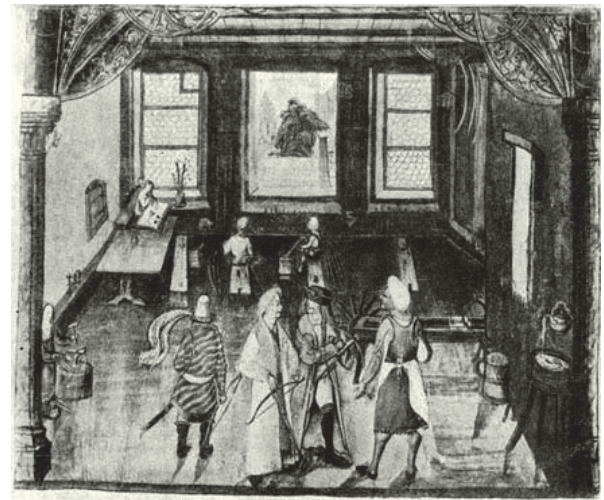

Fig 11. Crossbow makers' workshop, Krakow Balthasar Behem Codex, 1505. The men in the long coats are probably Polish nobility.
Neither the weapon nor the spanning device were something that an ordinary blacksmith could make; it required an expert, and, more than that, a culture of artisanry. Guilds in the towns such as Venice and Augsburg had very strict rules on the production of these weapons, made for a lucrative export market. The crossbow was expensive, costing as much as two swords or three tuns of beer $^{\text {Ixvii }}$, and the marksman who carried one was still "skilled labor" and was well paid as we can see in the letter from Matthias Corvinus.

\section{The firearm}

The Mongols brought many hitherto unknown weapons and techniques with them to Europe during their invasion in 1241. During the Battle of Mohi in 1241, the Mongols apparently used a special type of gunpowder weapon called a fire lance ${ }^{\text {Ixiii }}$, and in the siege of Pest that same year, the Mongols used rockets called fire arrows ${ }^{\text {Ixix }}$. Europeans were shocked by pyrotechnic weapons of this type, especially the deadly fire lance, which was an early type of firearm that had reached military significance in China.

Within a relatively short time though, they had learned the secret. Roger Bacon published the formula for gunpowder in his Opus Majus in 1267, and may have done so in encrypted form 20 years earlier. Gunpowder weapons may have been used in the successful defense of Kraków against the Mongols in 1287. Firearms were definitely used in the first successful defense of Moscow against them in 1380.

Fig 12, Czech Pistala, circa 1430. Author's illustration, based on photo of antique. Weapons like this won the hussite wars.

But it was during the hussite crusades of the 1420s and 1430s that firearms came to the forefront of warfare in spectacular fashion. The Czechs, under pressure of potential annihilation in the form of a massive crusade, made numerous field-expedient improvements to the firearm which have left us the words pistol (piśt'ala) and howitzer (boufnice). The hussite wars are far too complex and vast a subject to get into here, but suffice it to say that their impact was strongly felt throughout Europe, and the forges of 
many European cities, from Venice to Nuremberg, from Prague to Bruges, began to fashion guns.

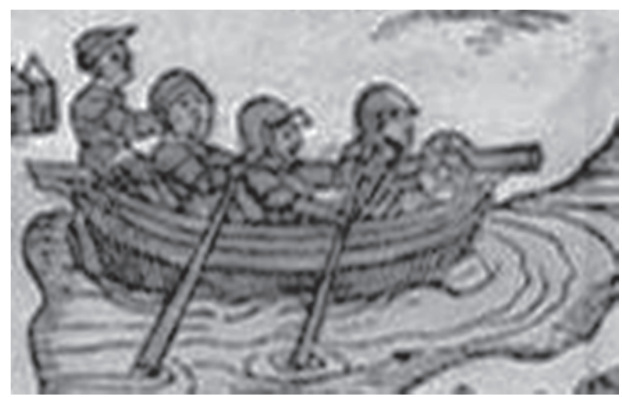

Fig 13 Detail from Olaus Magnus, Carta Mariana, river boat with pintle-mounted bow gun. Guns were used like this frequently throughout the river systems of the Baltic and north-central Europe, and were often breach-loading weapons.

In many cases it was the Czechs themselves who continued to be the direct impetus for this, because neither the war wagon nor the firearm were easily transferable technologies. In Poland, after clashing with hussites in 1427 during one of their socalled "beautiful rides," and experiencing with some shock their formidable new tábor gun wagon system, the town council of Kraków met to discuss upgrading the town arsenal and adding some of the modern Czech style weapons. In the $15^{\text {th }}$ Century, the firearm became part of the urban culture. Most towns already had a crossbow shooting range, by 1450 it was common for towns to have a firing range. We know that in many towns in Flanders special combat guilds were dedicated to crossbows (with the patron saint of St. George), and firearms (with the patron Saint of St. Barbara) ${ }^{\text {Ixx }}$.

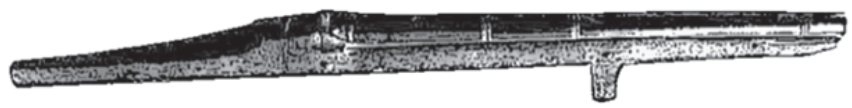

Fig 14. By the second half of the $15^{\text {th }}$ Century, the pistala was evolving into a more manageable weapon which looked a bit more like what would come to be the arquebus, as we can see with this small hook-gun from circa 1470. The hook was used to stabilize the gun over the walls of a war-wagon, or a fortification, or a boat, though it was not necessary to have support to fire the weapon. Illustration by author, based on an antique.

From their notes we know that it was determined at that time that the entire town only had two band boschen (hand guns) at the time and none of the two-handed hussite warflails or flegels. So the town elected to purchase eighty-seven new hand boschen and 147 war-flails to augment the existing guild arsenals, and allocated a substantial amount of money to buy or make them ${ }^{\mid \mathbf{x x i}}$. The shift from crossbows to guns remained gradual, though; at a muster in 1443 each citizen was ordered to appear with both pixides and balistas (i.e. crossbows) ${ }^{\text {Ixxii }}$. Nevertheless, it was in the towns like Kraków where the skills gradually transferred, as the local guilds figured out the new technology. Without 
a doubt journeymen from Bohemia also spread their skills to other towns north and west. All the towns were linked through their guild journeymen.

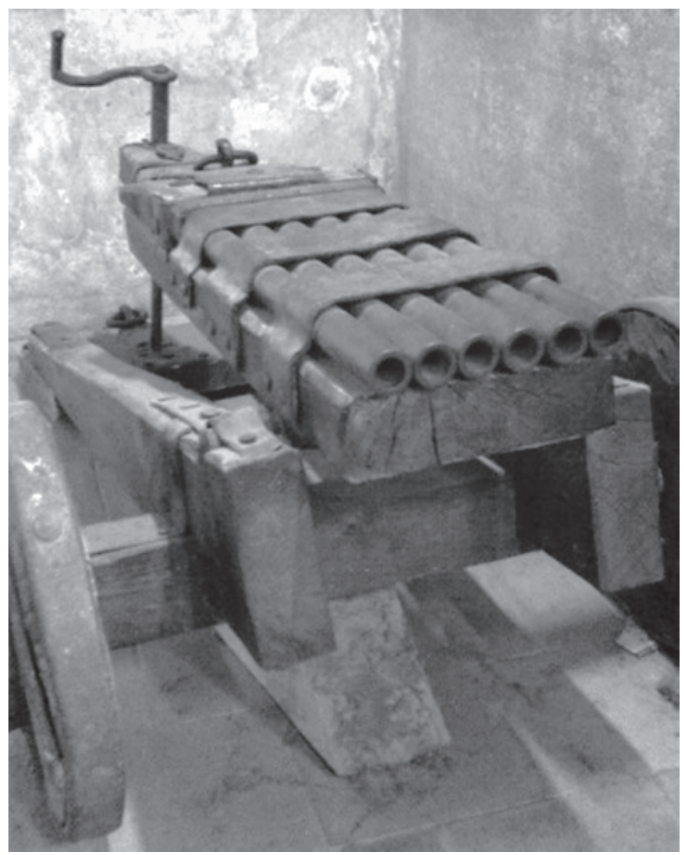

Fig 15 Czech volley gun of six barrels, Prague, mid-15th century (estimate). Photo courtesy of Ben Floyd, used with permission. Note the aiming mechanism for changing the elevation. This particular detail also appears frequently in period artwork.

The hand portable weapons were the equivalent of a 20 to 10 gauge shotgun, firing slugs in most cases rather than shot. Larger trestle guns were light cannon in the 15 to $20 \mathrm{~mm}$ range, and the houfnice was $30 \mathrm{~mm}$. Using gunpowder weapons required considerable skill. In addition to the inherent danger of maintaining a lit fuse in the vicinity of live gunpowder, before the invention of corned powder, gunners had to know how to mix gunpowder in the field. The simple innovation of soaking powder in alcohol and pushing it through a sieve to dry out led to a dramatic improvement in the reliability, power and accuracy of all European firearms. The forges of Prague and Tabor churned out weapons which were much improved over the original Chinese fire lance, an no longer had to be ignited from a flame pushed into the barrel.

The pistala gradually took on the look of a crude arquebus, with a longer barrel conferring better range and accuracy. It was triggered by a serpentine, a spring-loaded lever which would touch the match to a hole that was drilled into the barrel so that it could be ignited much more easily. This was the basis of what became the matchlock and, ultimately, all modern firearms, but the technology was fairly slow to spread and still required a great deal of skill to use. It wasn't until the $16^{\text {th }}$ century that routine 
training of hand-gunners was becoming something like a known quantity. Until then it was the Czechs themselves who often fought as mercenaries, bringing their guns with them, and often their wagons.

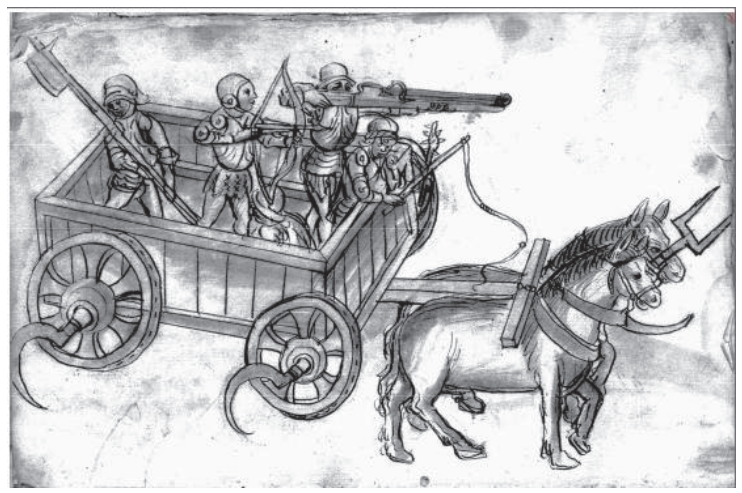

Fig 16 war wagon, unknown origin. Late $15^{\text {th }}$ century (estimated). Note the scythes protruding from the wagon wheels and possibly from the horses' harnesses as well.

\section{The war-wagon}

In the first battle of the hussite Wars, a skirmish at Battle of Sudomeřr, a mere 400 hussite infantry with twelve war-wagons defeated 2,000 cavalry. It was a precursor of things to come.

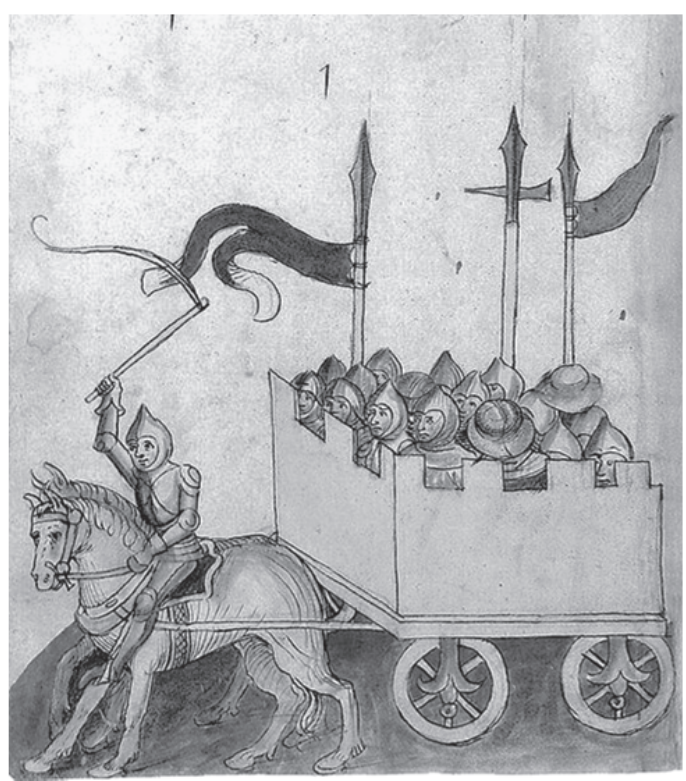

Fig 17 War-wagon, Bellifortis, Konrad Keyser, 1405 AD. Once again we see the scythes on the wagon wheels. Are they real, or an object of fancy? 
The war wagon was a development of the simple farmers-wagon, with some modified design features to make it useful for war. Wooden panels were added to the side, to provide an extra layer of protection against arrows and bullets. Ammunition boxes were mounted inside, and loopholes were built to shoot through. Larger wheels were added to maintain good mobility in spite of the extra weight. In some cases, apparently, scythes were mounted on the wheels or the sides of the wagons, though in what precise configuration it is not known for certain. Most importantly, guns were mounted on the wagons, on pintles, or trestles, or simply used with hooks to hang over the sides.

War wagons were nothing new. The Dutch called a wagon fort a heerlager, the Germans called it a wagenburg. War wagons may have been used in the early battles of leading up to Legnano in Italy, and were employed by the Scythians, and the Goths famously at Adrianople. But the way the Czechs were using war wagons, with guns and crossbows and cannons, was indeed new, and created quite an impression on the Germans during the repeatedly disastrous, failed invasions into Bohemia during the 1420's-1430's. Of course the idea didn't come from nowhere, and Jan Ži either contrary to what is often suggested. We can see them clearly for example in Konrad Keyser's famous Bellifortis from 1405, fifteen years before the hussite wars started.

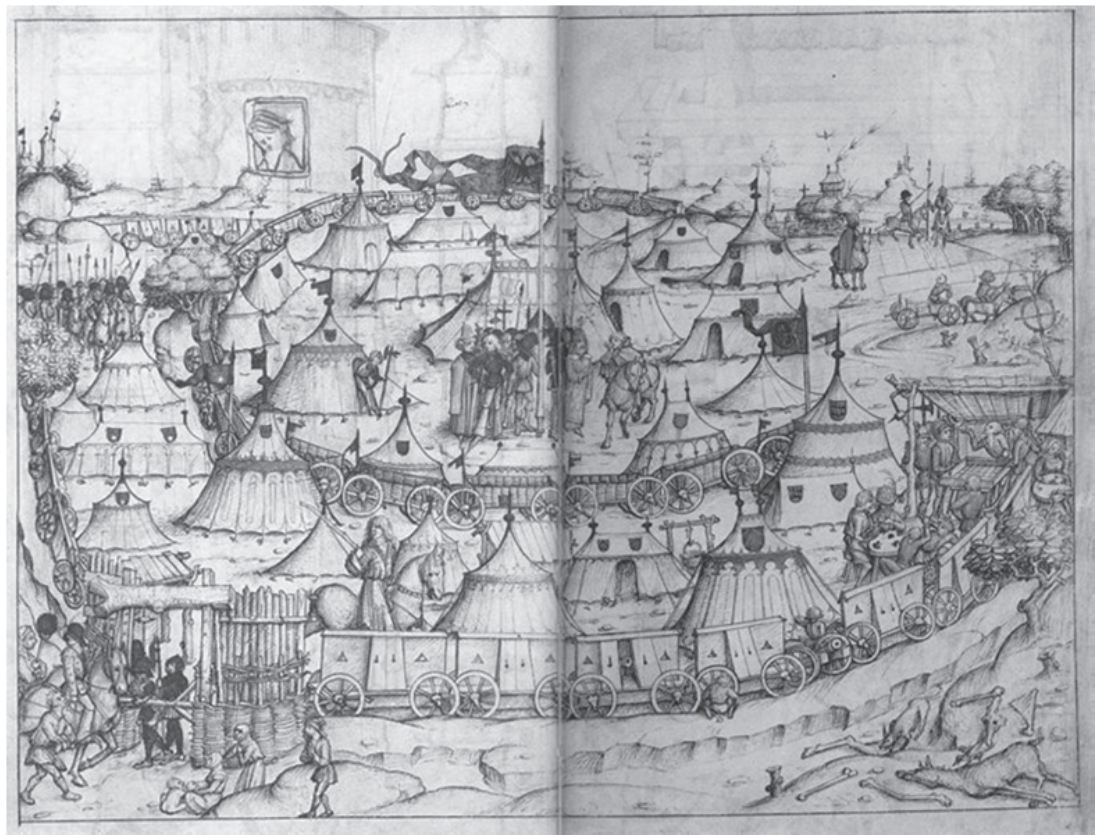

Fig 18. War wagons formed into a defensive laager, with the heavier gun wagons on the outside of the ring, and the lighter supply wagons on the inside. Note the shooting apertures and the small doors which open to reveal a pintle-mounted cannon. 
But the Czechs seem to be the first to have deployed them effectively and consistently, because their wagon forts proved more than capable of breaking up the charges of heavy cavalry in the hussite Crusades, just as they would later prove so effective against the arrows of horse archers. The difference was in two things: the technology added to the mix, crossbows, guns, mantlets and protective panels, possibly iron plates; and the tactics they developed for their use.

Just as with pikes, it is a common misconception that the war-wagons or tábor were only used in a static defense as the wagenburg. In many key battles during the hussite Wars and afterword these wagons were used aggressively, such as at Kutná Hora in 1421. Advancing in columns with the more heavily armored wagons on the outside and lighter supply wagons on the inside, they drove into enemy formations ${ }^{\text {Ixiii }}$. When under fire too heavy to use horses the large crews could easily push the wagons at a walking pace, and wooden mantlets were also created to protect horses from enemy gunfire.

The crews of the war wagons were large, up to twenty men, and armed with a variety of weapons. Most carried pikes, halberds, and especially the militarized two-handed flegel or flail, the characteristic hussite weapon (of the general configuration also seen in fechtbucher, i.e. Paulus Hector Mair). Initially, for ranged weapons they were mostly armed with slings and the simpler type of crossbows. But as the towns got more involved $^{\text {Ixxiv }}$ with the hussite Crusades, more and better ranged weapons including the statchel-type heavy arbalest crossbows and increasingly sophisticated firearms and small cannon from the hydro-powered urban mills and workshops became available to the hussite armies.

In 1440 hussite war-wagons in the army of Jan Hunyadi helped defeat Ottoman cavalry at Szekszárd ${ }^{\text {Ixxv }}$ and again at Gyulafehérvár in $1442^{\text {Ixxvi }}$. In these two battles the hussites deployed what would later become a standard tactic: the war-wagons wheeled around to take the enemy army in the rear of their column, sowing chaos and panic in their ranks. The Russians would use virtually the same tactics 100 years later in the Battle of Molodi in 1572.

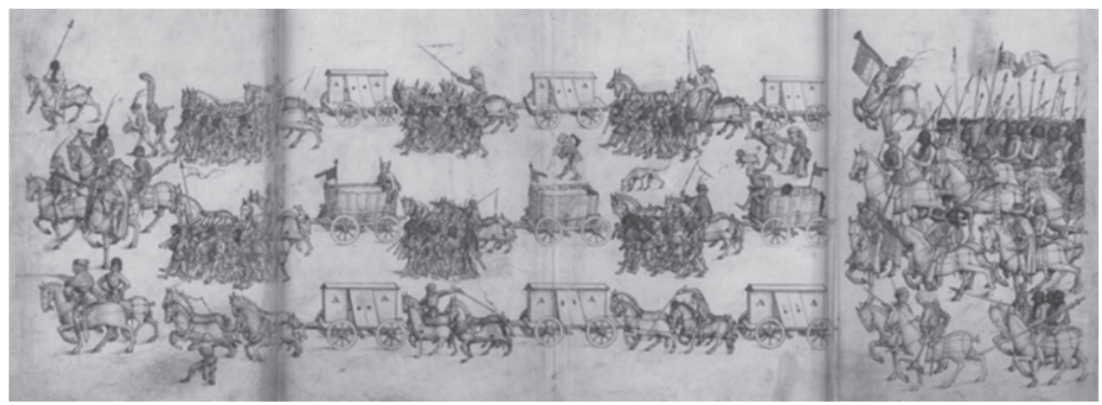

Fig 19 Mittelalterliches Hausbuch von Scbloss Wolfegg, 1480, $51 \mathrm{v}$. An army on the march, with simple mantlet-style war-wagons carrying small cannon. Note also mounted crossbowmen used as scouts, hand-gunners and crossbowmen in mixed formations, heavy infantry in separate formations. 
Długosz 1470 George Poděbrady stands talllxxvii It now looks as if George Podébrady is gaining the upper hand. He has equipped his troops with battle wagons and sent them against Matthias in Moravia; but, when the latter does not dare risk a pitched battle, for he has lost many men by desertion, Podëbrady withdraws his army and tries to put an end to the protracted siege. Having captured three of the bastions and supplied the bungry townspeople with provisions, he is planning to go to Trnava, but then Matthias' army of mercenaries arrives on the scene and it looks like they are going to have to fight it out; but the two armies avoid each other: the Hungarians as they cannot attack Podébrady because of his wagons fitted with scythes, the Czechs because they cannot pursue the Hungarians in such precipitous, awkward places. In the end Podébrady sends to Matthias suggesting that the two of them fight a duel in front of the two armies or else fix a place and a day for a pitched battle.

Długosz describes a nearly identical standoff in 1469, and in 1468 he mentions that Poděbrady was able to retire from the battlefield safely because "nobody dared to attack him" or his force consisting "mainly of peasants." By which he may have meant peasants, but it may also have been a generic reference to commoners, in this case burghers.

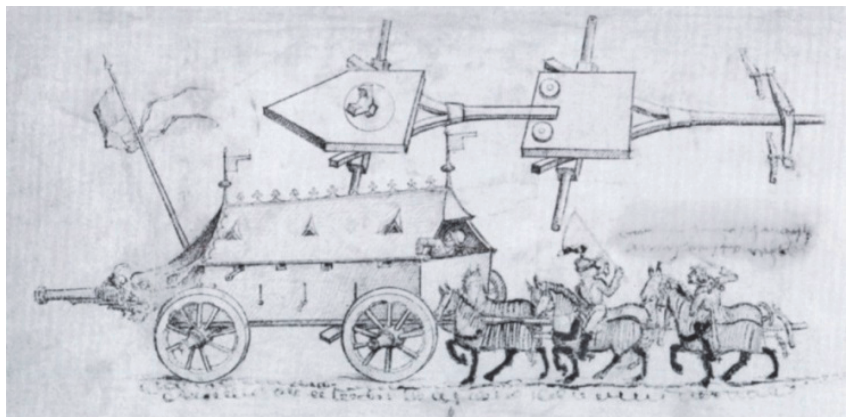

Fig 20, Wolfegg, folio $52 v$ 'Kampfwagen'. A more realistic painting of a war wagon, pushed rather than pulled by what appear to be armored horses. The axle design appears to allow the wagon to be steered from the inside (notably the same design can be seen in Talboffer's Bellifortis inspired 1459 edition, $\boldsymbol{M S}$ Thott.290. $2^{\circ}$, folios 15v, 37v)

New hand weapons were also critical to the success of these artisan armies. The morgenstern, the godendag, the famous hussite flail, the halberd, and the pike all enhanced the efficacy of infantry in the late medieval era. Kraków bought flails as well as guns after their encounter with hussites. Another important invention (or refinement) was the Lithuanian style pavise, or mini-pavise. This is a special type of shield, smaller than a full-sized pavise (similar in size to a Roman scutum, large enough to provide a great deal of cover but still small enough to carry on an arm if necessary) which was characterized by a strong central rib or raised section. These were made of laminated materials which seemed to have some efficacy in stopping the bolts of the very powerful crossbows, the bullets of firearms, and the arrows of the steppe nomads. The details of their construction remain something of a mystery. 


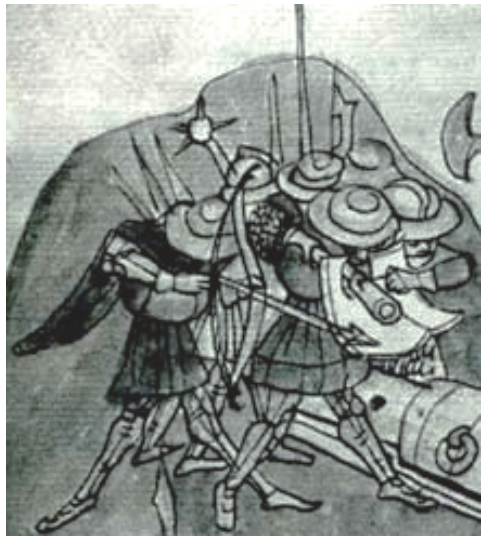

Fig 21. Czech or German gunners in 1437, using a sloped gunshield.

In period art we also see what appear to be curved steel mantlets, similar in design to the sloped armor seen on modern tanks, being used by Czech and German gunners. The guns and the crossbows, the pavises and the new hand weapons like the pike, the halberd and the flail all played a specific role, which was for the pitched battle in the open, formation vs formation. But formations inevitably broke up under the stress of combat, and when that happened, smaller weapons became necessary. This is why the sidearm was so vital. Many sidearms were used, including maces, axes, and hammers especially, and the ubiquitous dagger. By far the most popular and prestigious sidearms however, were swords and messers, and these above all else, marked an individual as a serious soldier.

It is perhaps not a coincidence that the Swiss, so famous for their success when battles reached the chaotic stage of a collapsing pike square, very often carried longswords as sidearms. We can see from period art that this was often the case with the Poles, Czechs and Germans as well.

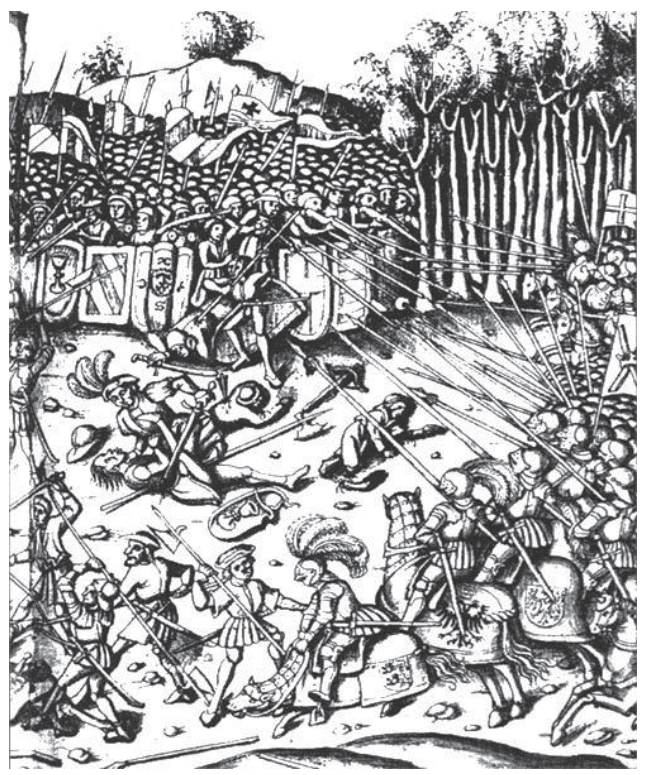

Fig 22. Czech bussite mercenaries in action, from the Landshut War of Succession, 1504

You can see the hussite chalice on some of the shields and the Hapsburg double eagle on some of the horses. Of special interest, this Bohemian army may have been the one led by the fechtbuch author and military leader Ludwig von Eyb. This was also the same war in which the famous free imperial knight Gottfried "Götz" von Berlichingen lost his hand. Note the use of kriegsmessers and (two handed) longswords as sidearms, carried by not only all the lancers, but also all the infantry. Note also the crossbow alongside the primitive early-arquebus firearms, crossbows were still battlefield weapons at this time. You can clearly see the brutal effects of the swords on the body in the center with a severed arm and leg. Image is a facsimile of an illustration from the chronicle of Ingolstadt, original image source is Zainer, Andreas: Chronik des Landshuter Erbfolgekriegs - BSB Cgm 1598, Ingolstadt, 1. Viertel 16. Jh. [BSB-Hss Cgm 1598] 


\section{The longsword as sidearm}

Finally we also see the further development of both the longsword and its cousins, as well as the fencing systems designed for their use. New techniques were being developed aggressively at this time, and the burghers were a big part of this trend. We can see in period artwork, and read in period records, that longswords and kriegsmessers or two-handed sabers were being carried by militia and mercenaries, both cavalry and infantry, throughout Europe. Contrary to the perception of some, the longsword remained in wide use in this fashion well into the $16^{\text {th }}$ century. It was a sidearm, but an extremely important one, since the primary weapons such as pikes and guns were so limited, especially in the chaos which ensued when the formation broke up. If not for the efficacy of the longsword as a sidearm, it seems unlikely that so many militia, soldiers, and mercenaries would strap them on their hip and drag them around the roads and paths of Europe.

\section{The citizen police force}

One fact of life in a medieval and Early Modern free city which probably seems the most incredible to modern readers, is that the citizens were the police force. Though most of the towns employed a few low-paid town guards to manage entry and exit from the town gates during the day when the streets thronged with citizens, foreigners or professionals were simply not trusted with the towns security at night, when it would just be too easy to open a gate to some enemy. As a result, citizens had no choice but to strap on armor, heft a halberd, and march around town in the cold Central European night with a lantern in hand, breaking up fights, warning late night revelers to quiet, and locking up miscreants in the 'fools house' or the jail.

The town watch was both police and fireman for a night, since fires were another major threat. Duty started when the evening bell rang, around 8 or $9 \mathrm{pm}$, and lasted all night long. Each watchman had to show up with armor, a primary weapon (a polearm or a crossbow or a gun) and a sword ${ }^{\text {lxxiii }}$. Though the halberd was the symbol of the watchman's authority, and was useful for example to block an alley with points, during altercations in the narrow streets of the town the weapon most typically used in a fight was the sword $^{\text {lxxix }}$. Not always to kill either, because there could be many repercussions to killing. For example, a grocer in Mindelheim was prosecuted in the $17^{\text {th }}$ Century for striking a peasant with the flat of his sword - for mocking him for standing guard without a gun ${ }^{\operatorname{lxx} x}$. Encounters with the town watch were not always so peaceful and could escalate into real violence ${ }^{\mid \mathbf{x x x i}}$ but every effort was made to prevent that kind of trouble.

\section{PERSONAL VIOLENCE}

In most towns under German town law, the citizens not only had the right to bear arms, they were obligated to keep weapons in their homes ${ }^{\text {Ixxii }}$. Citizens were also obligated the assist the town guard in the event of danger ${ }^{\text {Ixxiii }}$. Due to the potential 
consequences of escalating violence, civilians also frequently used the flat of the blade in altercations. In one incident in Augsburg in 1591, a baker named Caspar Rauner, was drinking and gambling in a pub when he insulted a weaver named Ausfichlager from Nordlingen (in a very bad way). The baker got his sword and challenged Ausfichlager to fight in the street, which he eventually did, killing Rauner. In his defense, Ausfichlager told the magistrates that he had mostly hit Rauner with the flat of his blade, only 'jabbing him' once in the armpit ${ }^{\text {Ixxiv }}$. Rules governing weapons were strict, though with a few exceptions like Nuremberg, most towns allowed carrying weapons, some allowed almost any weapon, but it was the sword, symbol of the citizen's status, which was most often carried.

Laws on the use of weapons were strict, you could be fined for drawing a blade, or for striking or cutting someone, but like in the Wild West, it was the person who initiated violence first was the one who got into the most trouble. Under German town law, murder was something done in secret. Manslaughter covered crimes of passion, and violence done to preserve ones honor. Manslaughter could be deemed excusable by the town council, however it might still lead to vendettas and revenge killings from the victim's family, typically a large wergild had to be paid.

\section{CONCLUSION}

With the fencing systems centered around the longsword, as with the crossbow, the firearm, and the war-wagon, we can perhaps see another means by which the burghers and craft artisans of the medieval era, among others, could apply their considerable skill to the problem of warfare. Though faced by formidable enemies ranging from prelates of the Church, to princes, to kings and emperors, and the forces of the Mongol Horde and the Ottoman Empire, the burghers proved to be as resourceful as they were sophisticated. In this essay I have attempted to show that they were often involved in wars and conflicts, both of a limited type within their city walls and brutal, full scale wars beyond them. The toughest of the medieval towns, places like Gdańsk, Wrocław, Prague, Berne and Zurich, proved their mettle in warfare and changed European history. It remains to be seen exactly what role the Kunst Des Fechten played in the pivotal events of the late medieval era in central Europe, but there can be little doubt that it contributed to the ferocity of the town militia, and that the experiences of the militia influenced the art of fencing.

\section{BIBLIOGRAPHY, BOOKS}

Długosz, Jan (author), Michael, Maurice (translator), 1480 / 1997, The Annals of Jan Długosz : A History of Eastern Europe from A.D. 965 to A.D. 1480 [abridged], aka Annales seu cronicae incliti Regni Poloniae, IM Publications LLP

Nowakowski, Andrzej, 1994, Arms and Armor in the Medieval Teutonic Order's State in Prussia, Oficyna Naukowa MS, (Poland)

Lepszy, Leonard, 1912, Cracow, the royal capital of ancient Poland: its history and antiquities TF. Unwin (United Kingdom) 
Urban, William L., 2003 Teutonic Knights: A Military History, William L. Urban, Greenhill Books

Pirenne, Henri, 1910, Belgian Democracy, its early history, Manchester University Press (United Kingdom)

Janssen, Johannes (author), Mitchell M.A. and Christie, A.M., (translators) 1896, Geschichte des deutschen Volkes seit dem Ausgang des Mittelalters, "History of the German People at the close of the Middle Ages" in two volumes. Triibner, \& Co.

Kaminsky, Howard, 2004, A History of the Hussite Revolution Wipf \& Stock Publishers

Nyberg, Tore (Editor) 2004, Saxo and the Baltic Region, a Symposium 1 edition, University Press of Southern Denmark

Stone, Daniel, 2001 Polish-Lithuanian State, 1386-1795 (History of East Central Europe), University of Washington Press

Epstein, S.r. and Prak, Maarten, (editors) 2008 Guilds, Innovation, and the European Economy, Cambridge University press

Davies, Norman and Moorhouse, Roger, 2002 Microcosm, Portrait of a Central European City, Pimlico Press

Klassen, John, 1999 Warring Maidens, Captive Wives and Hussite Queens, East European Monographs

Tlusty, Ann, B., 2011, The Martial Ethic in Early Modern Germany, Palgrave Macmillan

Dollinger, Phillipe, 1988 The Hansa, history and culture, Dorset Press

Verbruggen, J,.F., 2002 The Art of Warfare in Western Europe during the Middle Ages Boydell Press

Forzani, Tip. del Senato, 1889, Statuti Delle Societa del Popolo Di Bologna,

\section{ARTICLES}

Johanek, Peter (2000) "Imperial and Free Towns of the Holy Roman Empire, City States in Pre-modern Germany?" A comparative study of thirty city-state cultures: an investigation The Royal Danish Academy of Sciences and Letters

North, M. (1997) 'The records of Lübeck and Hamburg, c. 1250-1330', in R.H. Britnell ed., Pragmatic Literacy East and West, 1200-1330

Friedrichs, Christopher R. (author), Griffeth, Robert, and Thomas Carol G., Editors) (1981) 'The Swiss and German city-states', in The City-State in Five Cultures,

Groten, M. (1997) 'Civic record keeping in Cologne, 1250-1330', in R.H. Britnell ed., Pragmatic Literacy East and West, 1200-1330

Eltis, David (1989) “Towns and Defense in Later Medieval Germany”, Nottingham Medieval Studies v. 33 .

Nicholson, Christopher 2010 "Between Menace and Utility: Handguns in Early Sixteenth-century Bohemia”, University College London, Skepsi Vol 1, Kent University (United Kingdom)

Ekdahl, Sven 1998 "Horses and Crossbows: Two Important Warfare Advantages of the Teutonic Order in Prussia”, published in The Military Orders, Volume 2: Welfare and Warfare

Olansky, Franitsek 1996 “The Role of John Jiskra in the History of Slovakia”, Institute of Historical Studies, Slovak Academy of Sciences, (Bratislava, Slovakia) 
Bartók, Barnabás, Major 2011 “János Hunyadi: Preventing the Ottomans from Conquering Western Europe in the Fifteenth century", U.S. Army Command and General Staff College, Ft. Leavenworth, Ks, USA

\section{REFERENCES}

Długosz, Jan (author), Michael, Maurice (translator), 1480 / 1997, The Annals of Jan Długosz :A History of Eastern Europe from A.D. 965 to A.D. 1480 [abridged], aka Annales seu cronicae incliti Regni Poloniae, IM Publications LLP

ii

Dupuis, Olivier, Les écoles d'armes à Strasbourg, 2007, page 14 (used with permission)

iii

iv

Tlusty, Ann, B., 2011, The Martial Ethic in Early Modern Germany, Palgrave Macmillan, page 9

Eltis, David, 1989, “Towns and Defense in Late medieval Germany”, Nottingham Medieval Studies $\mathrm{v}$. 33, page 1

v Eltis, David, 1989, "Towns and Defense in Late medieval Germany", Nottingham Medieval Studies $\mathrm{v}$. 33, page 1

vi Tassava, C.J. "Launching a Thousand Ships: Entrepreneurs, War Workers, and the State in American Shipbuilding, 1940-1945." Northwestern University Ph.D. Thesis. June 2003

vii

Brennecke, Jochen Geschichte der Schiffahrt, Künzelsau 1986 (2nd ed.), page 62

viii

Verbruggen, J.F., 2002, The Art of Warfare in Western Europe During the Middle Ages, p 173

ix Verbruggen, J.F., 2002, The Art of Warfare in Western Europe During the Middle Ages, p 173

x Verbruggen, J.F., 2002, The Art of Warfare in Western Europe During the Middle Ages, $\mathrm{p}$ 173

xi Tlusty, Ann, B., 2011, The Martial Ethic in Early Modern Germany, Palgrave Macmillan, page 1

xii Schildhauer, Johannes, 1988, The Hansa, history and culture, Dorset Press, page 162. They list their source as: Kroppmann, K. : Die Wehrkraft der Rostocker Amter, in Hansiche Geschichtblatter, 1886, p. 166

xiii Schildhauer, Johannes, 1988, The Hansa, history and culture, Dorset Press, page 162. They list their source as: Kroppmann, K. : Die Wehrkraft der Rostocker Amter, in Hansiche Geschichtblatter, 1886, p. 166

xiv Verbruggen, J.F., 2002, The Art of Warfare in Western Europe During the Middle Ages, p 173

xv Sammelhandschrift - Mscr.Dresd.F.98, f 266v.

xvi Verbruggen, J.F., 2002, The Art of Warfare in Western Europe During the Middle Ages, p 183

xvii Verbruggen, J.F., 2002, The Art of Warfare in Western Europe During the Middle Ages, p 174

xviii Eltis, David, 1989, “Towns and Defense in Late medieval Germany”, Nottingham Medieval Studies v. 33 
xix Gravett, Christopher, 1985 German medieval Armies, 1300-1500, Osprey page 14

xx Schildhauer, Johannes, 1988, The Hansa, history and culture, Dorset Press, page 164.

xxi Pirenne, Henri, 1920 'Recueil de documents relatifs à l'histoire de l'industrie drapière en Flandre', Brussels, 1920. (Translation by Ariella Elema)

xxii Verbruggen, J.F., 2002, The Art of Warfare in Western Europe During the Middle Ages, p 174

xxiii Gregorovius, Ferdinand, 1894 / 2002, Rome in the Middle Ages, vol. IV, part 1, Annie Hamilton (trans.), page 580

${ }^{\text {xxiv }}$ Forzani, Tip. del Senato, 1889, Statuti Delle Societa del Popolo Di Bologna, p. 471-481.

xxv Eltis, David, 1989, "Towns and Defense in Late medieval Germany", Nottingham Medieval Studies v. 33, page 5

xxvi Eltis, David, 1989, "Towns and Defense in Late medieval Germany", Nottingham Medieval Studies v. 33, page 5

xxvii Długosz, Jan (author), Michael, Maurice (translator), 1480 / 1997, The Annals of Jan Długosz IM Publications, p 192

xxviii Davies, Norman, and Moorhouse, Roger 2002, Microcosm, Portrait of a Central European City, Pimlico, page 96

xxix Długosz, Jan (author), Michael, Maurice (translator), 1480 / 1997, The Annals of Jan Długosz IM Publications, p 193

xxx Długosz, Jan (author), Michael, Maurice (translator), 1480 / 1997, The Annals of Jan Długosz IM Publications, p 227

xxxi Długosz, Jan (author), Michael, Maurice (translator), 1480 / 1997, The Annals of Jan Długosz IM Publications, p 229

xxxii Lepszy, Leonard, 1912, Cracow, the royal capital of ancient Poland: its history and antiquities, pages $48-53$

xxxiii Długosz, Jan (author), Michael, Maurice (translator), 1480 / 1997, The Annals of Jan Długosz IM Publications, p 232

xxxiv Johanek, Peter, 2000, "Imperial and Free Towns of the Holy Roman Empire, City States in Premodern Germany?” A comparative study of thirty city-state cultures: an investigation The Royal Danish Academy of Sciences and Letters

xxxv Catholic Encyclopedia: History of Cologne

xxxvi Catholic Encyclopedia: History of Cologne

xxxvii Eltis, David, 1989, "Towns and defense in late medieval Germany", Nottingham Medieval Studies v. 33, page 5

xxxviii Eltis, David, 1989, "Towns and defense in late medieval Germany", Nottingham Medieval Studies $v$. 33, page 6

xxxix Eltis, David, 1989, "Towns and defense in late medieval Germany", Nottingham Medieval Studies v. 33, page 4 
xl Brady, Thomas, A, 1978 Ruling class, regime and reformation at Strasbourg 1520-1555, Leiden: Brill, page 58

xli Brady, Thomas, A, 1978 Ruling class, regime and reformation at Strasbourg 1520-1555, Leiden: Brill page 58

xlii

Davies, Norman, and Moorhouse, Roger 2002, Microcosm, Portrait of a Central European

City, Pimlico, pages 121, 143)

xliii Davies, Norman, and Moorhouse, Roger 2002, Microcosm, Portrait of a Central European

City, Pimlico, page 110

xliv Davies, Norman, and Moorhouse, Roger 2002, Microcosm, Portrait of a Central European

City, Pimlico, page 144

xIv Davies, Norman, and Moorhouse, Roger 2002, Microcosm, Portrait of a Central European

City, Pimlico, page 112

xlvi Klassen, John, 1999, Warring Maidens, Captive Wives and Hussite Queens, John Klassen, East European Monographs, page 205.

${ }^{\text {xlvii }}$ Ehrenberger, Tomaš The 88 Most Beautiful Castles, Kartografie Praha a.s, pg. 133,

xIviii Source: Philip the Good, pages 88-90, Reference: Jan van Dixmude, Kronyk, 76-80 and

Hanserecess von 1431 bis 1476, ii (translated from Flemish to English by the author of the book, Richard Vaughan)

xlix Spielhagen, Friedrich, Düsel, Friedrich, Karpeles, Gustav, 1863, Westermanns Monatshefte, Volume 13 , page 33

I Kock, Reimar, 1549/ 1934 Von Pawel Beneken einem dudisken Helde: auss der Chronik von Reimar Kock, Kaffeman

li Salter, F.R. "The Hanse, Cologne, and the Crisis of 1468" The Economic History Review 3.1 (January 1931), pp. 93-101

lii Długosz, Jan (author), Michael, Maurice (translator), 1480 / 1997, The Annals of Jan Długosz IM Publications, p 513

liii Długosz, Jan (author), Michael, Maurice (translator), 1480 / 1997, The Annals of Jan Długosz IM Publications, p 535

liv Davies, Norman, and Moorhouse, Roger 2002, Microcosm, Portrait of a Central European City, Pimlico, page 116

Iv Długosz, Jan (author), Michael, Maurice (translator), 1480 / 1997, The Annals of Jan Długosz IM Publications, p 543

Ivi Długosz, Jan (author), Michael, Maurice (translator), 1480 / 1997, The Annals of Jan Długosz IM Publications, p 539

Ivii Długosz, Jan (author), Michael, Maurice (translator), 1480 / 1997, The Annals of Jan Dlugosz IM Publications, p 586

Iviii Davies, Norman, and Moorhouse, Roger 2002, Microcosm, Portrait of a Central European City, Pimlico, page 118 
lix

Davies, Norman, and Moorhouse, Roger 2002, Microcosm, Portrait of a Central European

City, Pimlico,), page 118

Ix Informal translation done by a friend Krisztina Nagy, in an unofficial basis from the

Hungarian Wikipedia article, the original source is here

bttp:// mek.osqk.bu/07100/07105/pdf/ matyaslev1.pdf

Ixi Franitsek Olansky, 1996, "The Role of John Jiskra in the History of Slovakia”, Institute of Historical Studies, Slovak. Academy of Sciences, Bratislava, Slovakia, page 24 (page 6 in the PDF)

Ixii Franitsek Olansky, 1996 "The Role of John Jiskra in the History of Slovakia", Institute of Historical Studies, Slovak. Academy of Sciences, Bratislava, Slovakia, page 27 (page 9 in the PDF) Ixiii

Franitsek Olansky, 1996 “The Role of John Jiskra in the History of Slovakia”, Institute of Historical Studies, Slovak. Academy of Sciences, Bratislava, Slovakia, page 27 (page 9 in the PDF) Ixiv

Barnabás Bartók, major, 2011, "János Hunyadi: Preventing the Ottomans from Conquering Western Europe in the Fifteenth century”, Major, U.S. Army Command and General Staff College, page 54

Ixv

Eltis, David, 1989, Towns and Defence in Later Medieval Germany Nottingham Medieval

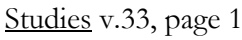

Ixvi Ekdahl, Sven, Horses and Crossbows: Two Important Warfare Advantages of the Teutonic Order in Prussia The Military Orders, Volume 2: Welfare and Warfare, edited by Helen Nicholson (Aldershot: Ashgate, 1998)

Ixvii Nadolski, Andrzej, 1990, Uzbrojenie w Polsce średniowiecznej 1350-1450, “Armaments in medieval Poland 1350-1450”, Polska Akademia Nauk, Instytut Historii Kultury Materialnej, page 471

Ixviii McNeill, William H. (1992), The Rise of the West: A History of the Human Community, University of Chicago Press, p. 492

Ixix Skurzynski, Gloria (2010). This Is Rocket Science: True Stories of the Risk-Taking Scientists Who Figure Out Ways to Explore Beyond Earth (illustrated ed.). National Geographic Books. p. 1958

Ixx Bert Gevaert, personal communication, 2012

Ixxi Nadolski, Andrzej, 1990, Uzbrojenie w Polsce średniowiecznej 1350-1450, “Armaments in medieval Poland 1350-1450”, Polska Akademia Nauk, Instytut Historii Kultury Materialnej, pages 470 and 472

Ixxii Armaments in medieval Poland, Page 472.

Ixxiii "Janos Hunyadi: Preventing the Ottomans from Conquering Western Europe in the Fifteenth century", Major Barnabás Bartók, U.S. Army Command and General Staff College (2011), page 42

Ixxiv "János Hunyadi: Preventing the Ottomans from Conquering Western Europe in the Fifteenth century", Major Barnabás Bartók, U.S. Army Command and General Staff College (2011), page 44

Ixxv "János Hunyadi: Preventing the Ottomans from Conquering Western Europe in the Fifteenth century", Major Barnabás Bartók, U.S. Army Command and General Staff College (2011), page 64 Ixxvi "János Hunyadi: Preventing the Ottomans from Conquering Western Europe in the Fifteenth century", Major Barnabás Bartók, U.S. Army Command and General Staff College (2011), Page 74 
Ixxvii Długosz, Jan (author), Michael, Maurice (translator), 1480 / 1997, The Annals of Jan Długosz IM Publications p 575

Ixxviii Tlusty, Ann, B., 2011, The Martial Ethic in Early Modern Germany, Palgrave Macmillan, page 40

Ixxix Tlusty, Ann, B., 2011, The Martial Ethic in Early Modern Germany, Palgrave Macmillan, page 29

Ixxx Tlusty, Ann, B., 2011, The Martial Ethic in Early Modern Germany, Palgrave Macmillan, page 53

Ixxxi Tlusty, Ann, B., 2011, The Martial Ethic in Early Modern Germany, Palgrave Macmillan, page 53

Ixxxii Tlusty, Ann, B., 2011, The Martial Ethic in Early Modern Germany, Palgrave Macmillan, page 1

Ixxxiii Tlusty, Ann, B., 2011, The Martial Ethic in Early Modern Germany, Palgrave Macmillan, page 35

Ixxxiv Tlusty, Ann, B., 2011, The Martial Ethic in Early Modern Germany, Palgrave Macmillan, page 114 